المتطلبات الأدائية لمقطوعات البيانو للأطفال مصنف (9 ؛ ) عند "إرنست بلوخ"

\title{
Ernest Bloch
}

م.د/ زينب عبد الفتاح إبراهيم

مقدمة البحث:

في بداية القرن العشرين عانت الموسيقى الأوربية في تغير مستمر ونمو مطرد نتيجة للأبحاث

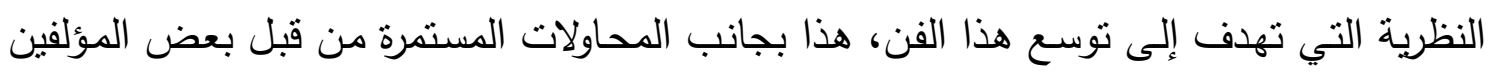

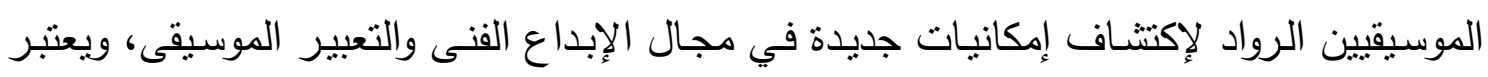

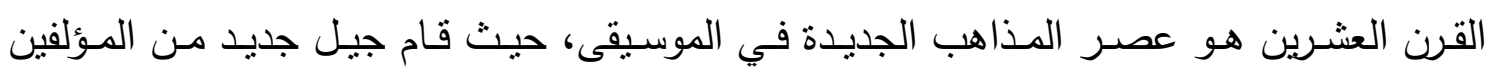

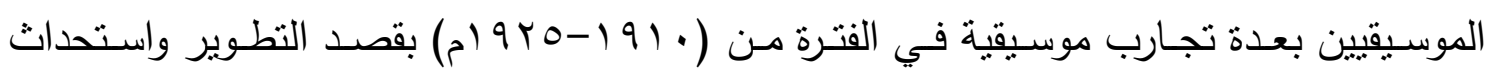

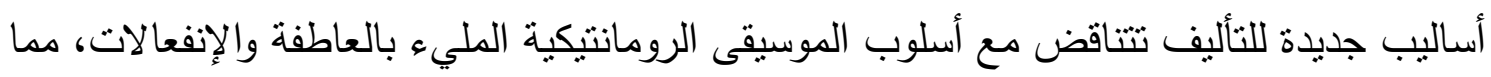
دعاهم لإيجاد أسلوب آخر يعكس روح العصر الذي يعيشون فيه (1). ولقد إهتم العديد من المؤلفين الموسيقيين منذ بداية القرن العشرين بالجانب التعليمى لآلة البيانو

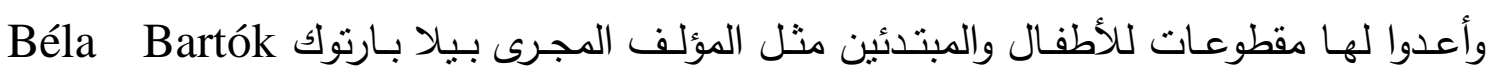

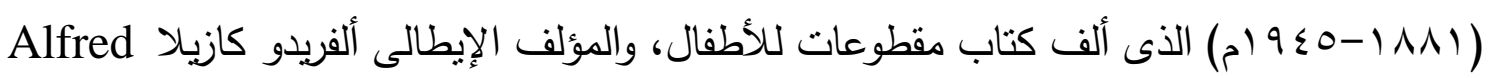
آراد

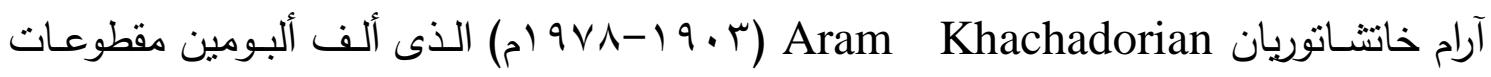

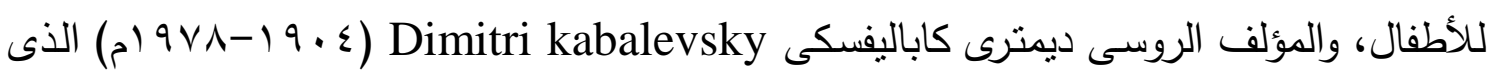

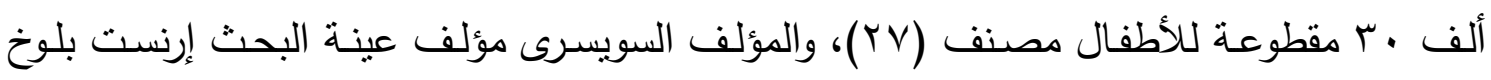
(1909-11 • Ernest Bloch

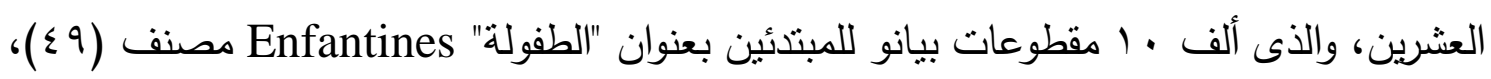

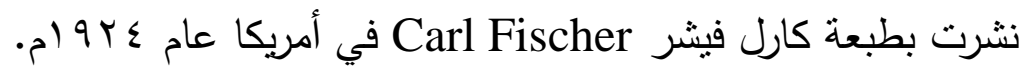

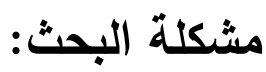

إقتصار إختيار العديد من دارسى البيانو بالسنوات المبكرة في مرحلة البكالوريوس بكلية التربية الموسيقية - جامعة حلوان على مقطوعات محددة ومكررة للمبتدئين وعدم التتوع في إختبارها،

• مدرس دكتور بقسم الأداء - شعبة بيانو - كلية التربية الموسيقية - جامعة حوان.

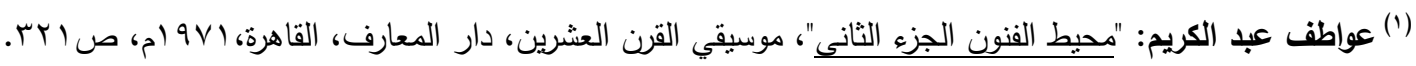

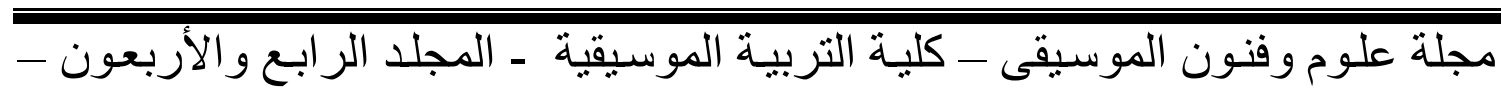

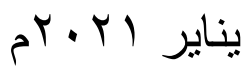


بالرغم من وجود العديد من مقطوعات البيانو المميزة للمبندئين، لذا رأت الباحثة أن تلقى الضوء على مقطوعات البيانو للأطفال مصنف (9 §) عند إرنست بلوخ التى تتاسب دارسى البيانو بالكلية.

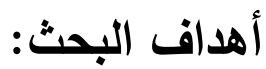

1- التعرف على سمات مقطوعات البيانو للأطفال مصنف (9 ؛) عند إرنست بلوخ من خلال التحليل البنائي والعزفي لعينة البحث. r- التوصل إلى المتطلبات الأدائية للتقنيات العزفية في عينة البحث من مقطوعات البيانو للأطفال

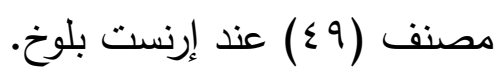
أهمبة البحث: مهنف:

التعريف بسـمات مقطوعـات البيانو للأطفال مصنف (9 ؟) عند إرنست بلوخ عينـة البحث والتوصل لأدائها بطريقة صحيحة، وتصنيف جميع المقطوعات من حيث المستوى العزفي، وإثراء

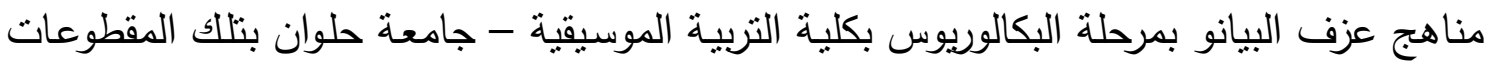
ليتمكن دارسى البيانو المبتدئين من إختيار ما يناسبهر منها.

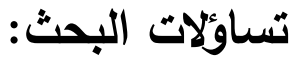

1- ما سمات مقطوعات البيانو للأطفال مصنف (9 § ) عند إرنست بلوخ ؟

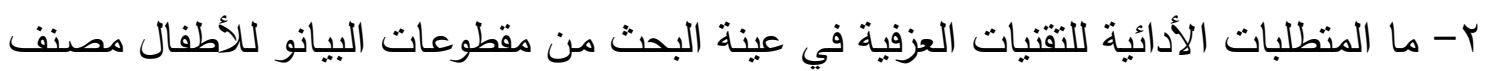

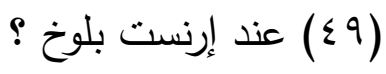

$$
\begin{aligned}
& \text { إجراءات البحث: } \\
& \text { أ) منهج البحث: }
\end{aligned}
$$

يتبع البحث المنهج الوصفي "تحليل المحتوى"، وهو المنهج الذي يقوم على وصف الظـاهرة

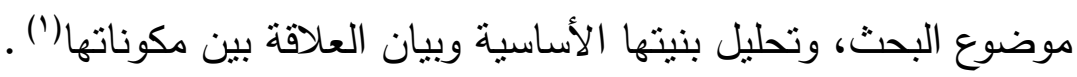

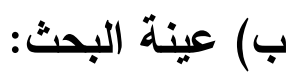

عينة منتقاة من مقطوعات البيانو للأطفال مصنف (9 ؛ ) عند إرنست بلوخ والتى تحتوى على

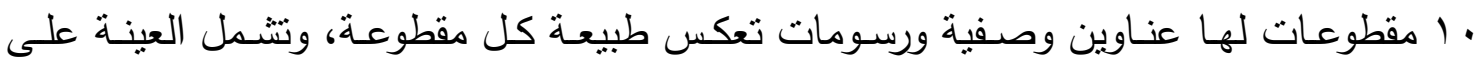

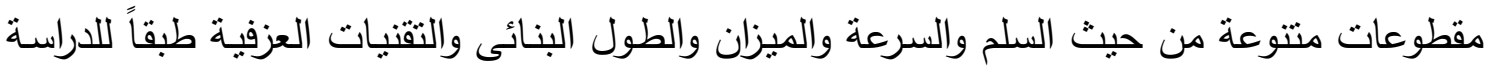

(1) آمـال صـادق وفؤاد أبو حطب: "مناهج البحث وطرق التحليل الإحصائى"، مكتبة الأنجلو المصرية، القاهرة اجو9 ام،

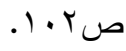

مجلة علوم وفنون الموسيقى - كلية التربية الموسيقية ـ المجلد الرابع و الأربعون - مبية

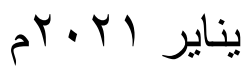


المسحية، وتلائم مستويات عزفية متتوعة للطلاب المبتدئين بمرحلة البكالوريوس طبقاً لإستطلاع

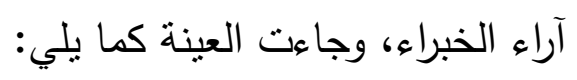

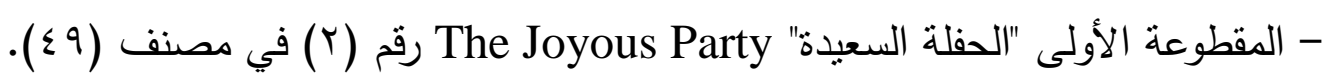

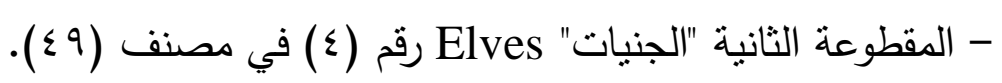

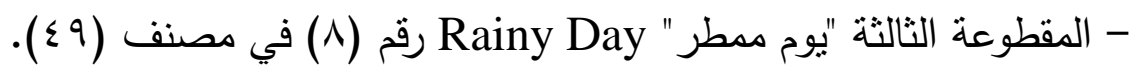
ج) حدود البحث:

- زمنياً: نهاية القرن التاسع عشر والنصف الأول من القرن العشرين في الفترة ما بين ( • ـ1 أ-

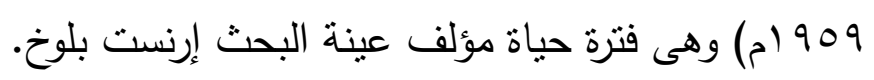
- مكانياً: سويسرا والولايات المتحدة الأمريكية. د) أدوات البحث:

- إستطلاع آراء الخبراء في المستوى العزفي المقترح لمقطوعات البيانو للأطفال مصنف (9 ؛ ) عند إرنست بلوخ.

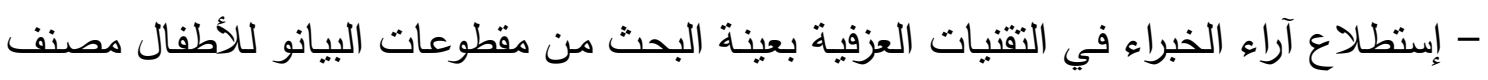

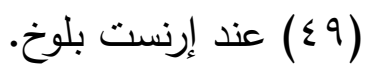
مصطلحات البحث:

1- Performance Techniques مقنيات الأداء هي المهارات الضرورية الخاصة بالعزف على آلة البيانو التي تهدف إلى عزف منقن ومعبر

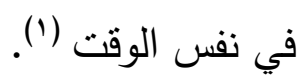

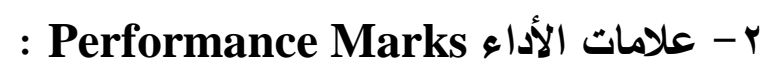

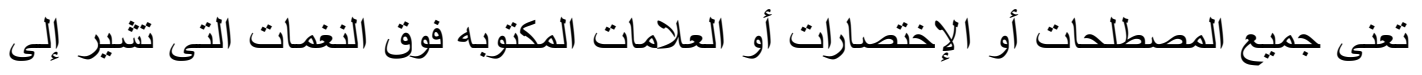

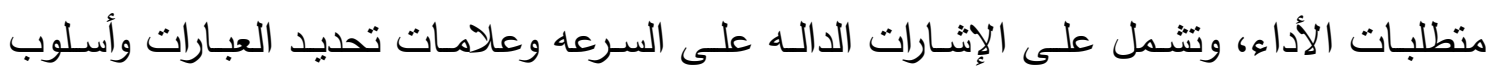
اللمس ونماذج إظهار طابع المؤلفه (†).

(1) Randel, Michael: "The Harvard Concise Dictionary of Music and Musicians", Harvard College Press, U.S.A, 1999, P.502.

(2) Agay, Denes:"Teaching Piano", Hamilton Printing Company, Vol.1, New York, 1981, P.603.

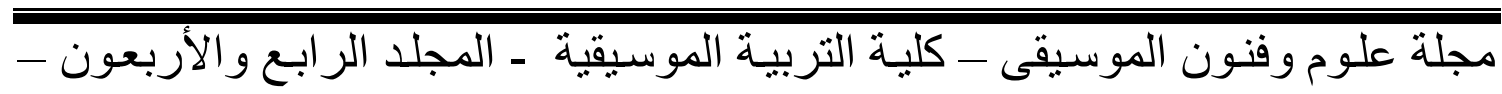

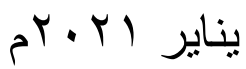




\section{ب- المقطوعات Pieces:}

مؤلفة آلية تصاغ في قالب ثنائي أو ثلاثي، وأخذت المقطوعات جزءاً من إهتمام المؤلفين

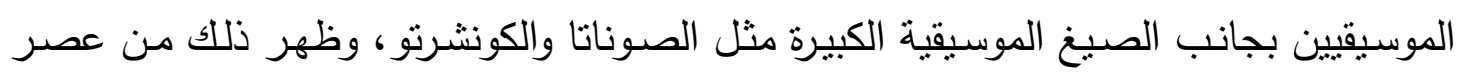
الباروك حتى القرن العشرين حيث إزدهرت المقطوعات وظهرت في أثكال وعناوين مختلفة (').

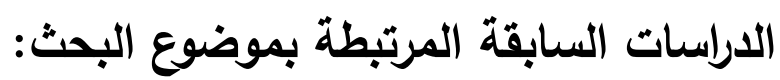

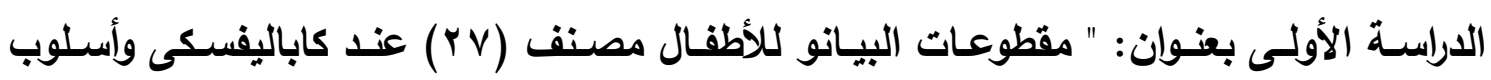

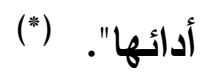
هدفت تلك الدراسة إلى التعرف على العناصر الموسيقية المختلفة التى إستخدمها كاباليفسكى في

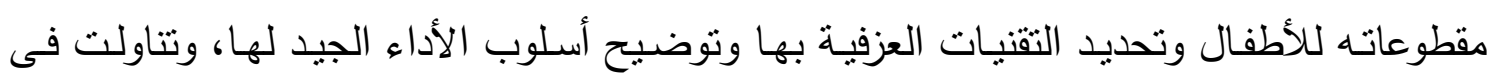

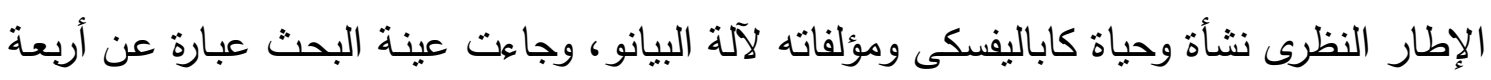

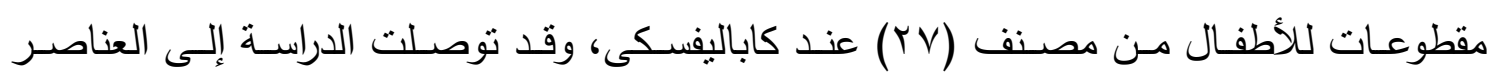

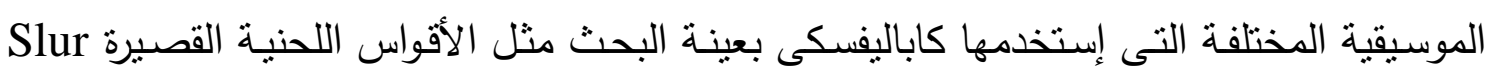

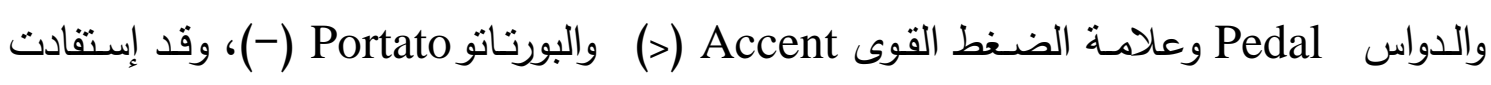
الباحثة من الإطار التطبيقى من خلال الدراسة التحليلية العزفية لعينة البحث وكيفية والبـة إستخلاص التقنيات العزفية ومحاولة تذليل المشاكل العزفية بالمقطوعات عينة البحث. الدراسة الثانية بعنوان: "أسلوب ايمي بيتش Amy Beach في تعليم التقتيات الفنية من خلال

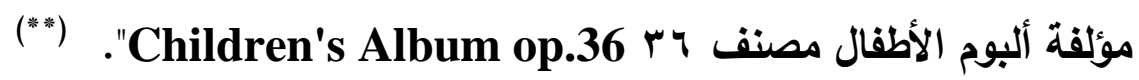
هدفت تلك الدراسة إلى دراسة أسلوب إيمي بينش المدنهج في تعليم تقنيات العزف على آلى آلة

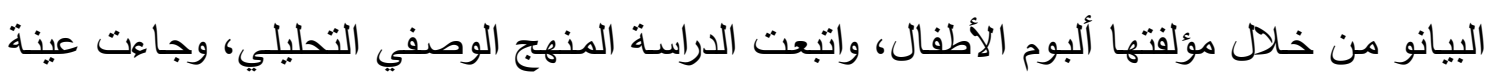

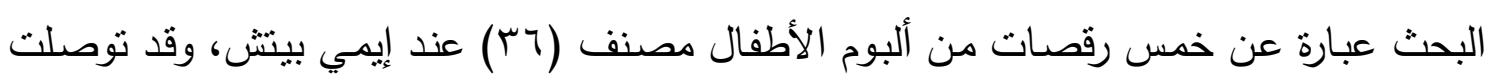

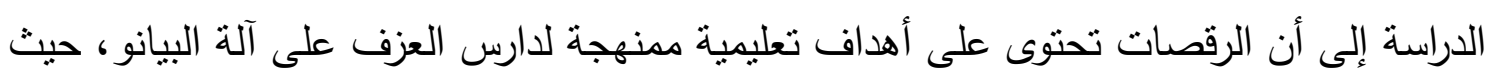

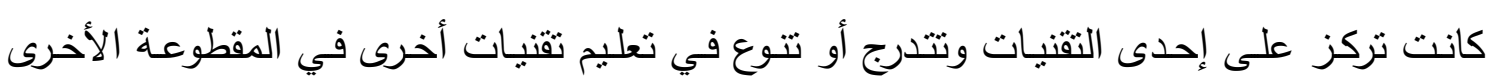

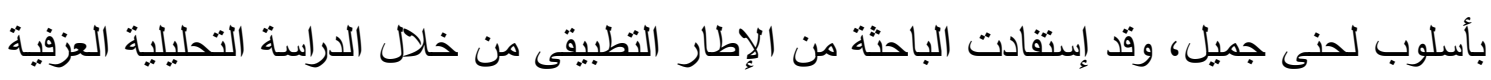

(3) www.thinkexist.com.

(") نجوى إيليا ثابت: بحث منشور ، مجلة علوم وفنون الموسيقى، المجلد السابع، كلية التربية الموسيقية، جامعة حلوان،

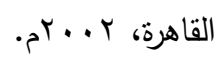
("* ماجدة مصطفى كامل: بحث منشور ، مجلة علوم وفنون الموسيقى، المجلد الخامس والعشرون، كلية التربية الموسيقية،

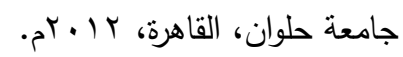

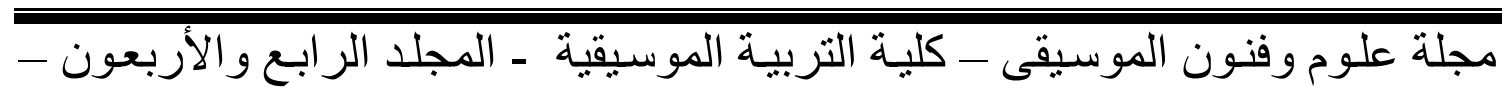

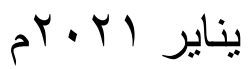


لعينة البحث وكيفية إستخلاص أسلوب إيمي بينت في تعليم النقنيات الفنية في تعلم آلة البيانو وكيفية أداء التقنيات الفنية بالرقصات عينة البحث. وينقسم البحث إلى جزئين: الجزء الأول: الإطار النظري ويشتنمل على البى 1- بعض مقطوعات البيانو للمبندئين في القرن العشرين. r- نشأة وحياة إرنست بلوخ. r- مؤلفات إرنست بلوخ لآلة البيانو.

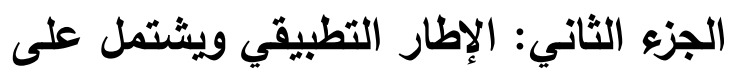

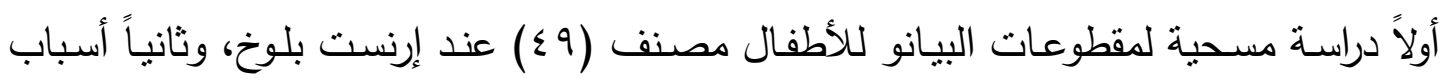

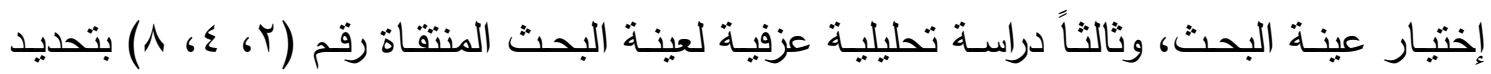
التقنيات العزفية وتوضيح منطلبات أدائها. الجزء الأول: الإطار النظري.

- بعض مقطوعات البيانو للمبتدئين في القرن العشرين: (1) جدول رقم (1) بعض مقطوعات البيانو للمبتدئين في القرن العشرين

\begin{tabular}{|c|c|c|}
\hline سنة التأليف & المؤلف & المقطوعات \\
\hline ع & 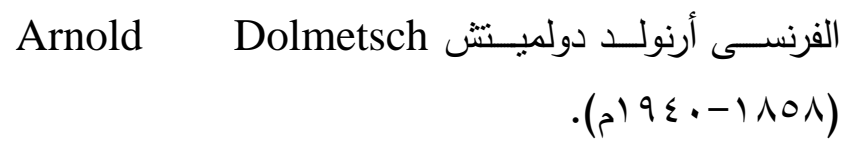 & $\begin{array}{c}\text { r ا مقطوعة سهلة } 12 \\
\text { Easy Pices }\end{array}$ \\
\hline سام & 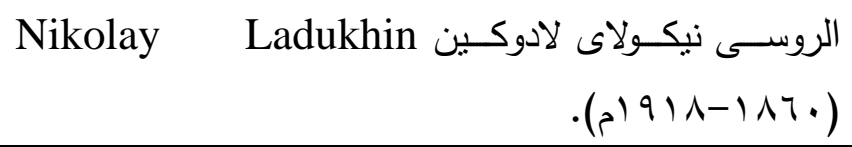 & $\begin{array}{l}\text { (1) مقطوعات للأطفال } \\
\text { Children Pieces }\end{array}$ \\
\hline م). & 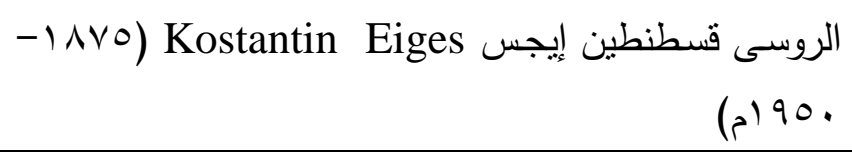 & 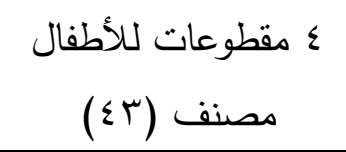 \\
\hline م & 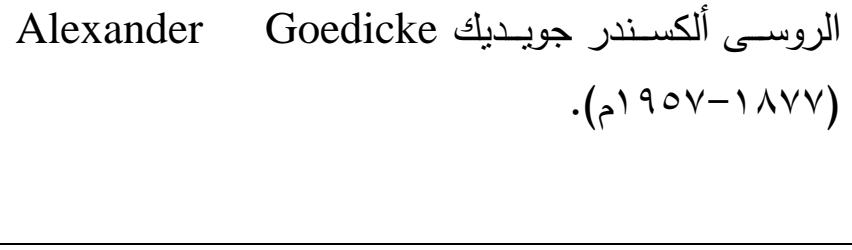 & 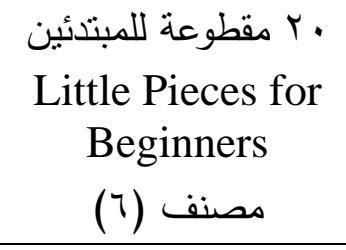 \\
\hline plarv & ألكسندر جويديك. & $\begin{array}{l}\text { 7 } 7 \text { مقطوعة سهلة } \\
\text { Piano Pieces }\end{array}$ \\
\hline
\end{tabular}

${ }^{(1)}$ Friskin James, Irwin Freundlich: "Music for the Piano", Dover Publications, Inc, New York, 1973.

مجلة علوم وفنون الموسيقى - كلية التربية الموسبقية ـ المجلد الر ابع و الأربعون -

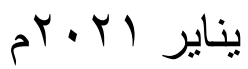


جدول رقم (1) بعض مقطوعات البيانو للمبتدئين في القرن العثرين

\begin{tabular}{|c|c|c|}
\hline سنة التأليف & المؤلف & المقطوعات \\
\hline & & مصنف (بr) \\
\hline كب4 & ألكسندر جويديك. & 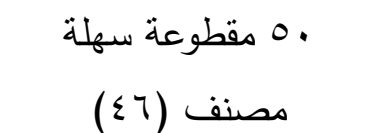 \\
\hline مب9 & ألكسندر جويديك. & 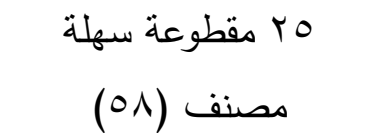 \\
\hline م & 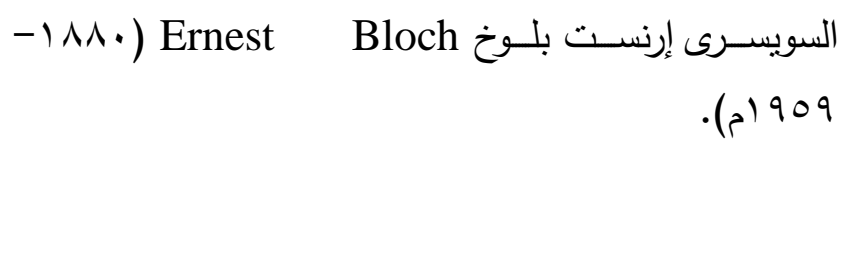 & 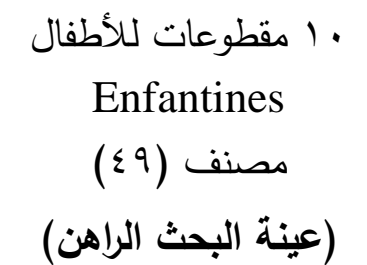 \\
\hline$p^{19.9}$ & المجرى بيلا بارتوك Béla Bartók ( (1) ו-0 9 (م). & 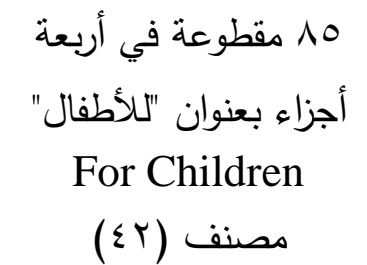 \\
\hline مام & 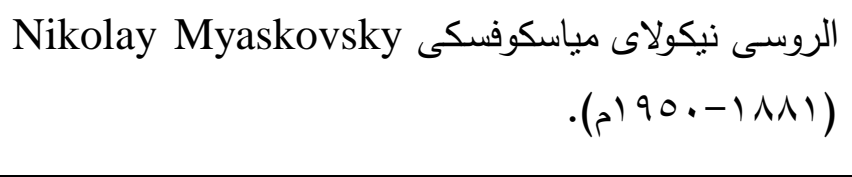 & $\begin{array}{l}\text { مقطوعات سهلة جداً } 1 . \\
\text { Very Easy Pieces } \\
\text { for Piano }\end{array}$ \\
\hline مب9 & 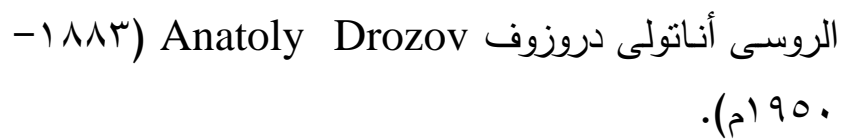 & $\begin{array}{c}\text { P مقطوعات للأطفال } 1 \text {. } \\
\text { Pieces for Children }\end{array}$ \\
\hline مبر & 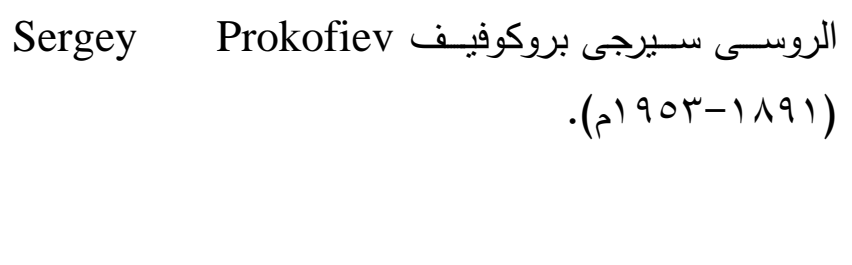 & $\begin{array}{l}\text { "موسيقى للأطفال" مقطوعة بعنوان } \\
\text { "مusic for Children } \\
\text { مصنف (70) }\end{array}$ \\
\hline م & 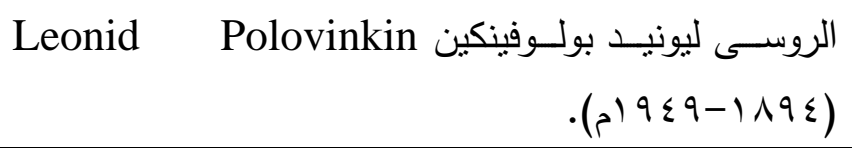 & $\begin{array}{c}\text { مقطوعات للأطفال } \\
\text { Children`s Pieces }\end{array}$ \\
\hline مب9 & 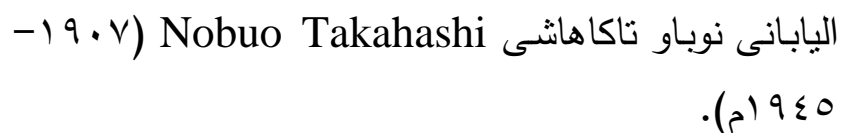 & ^ مقطوعات للبيانو \\
\hline
\end{tabular}

مجلة علوم وفنون الموسيقى - كلية التزبية الموسيقية ـ المجلد الر ابع والأربعون -

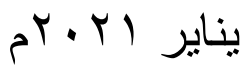


جدول رقم ( ) بعض مقطوعات البيانو للمبتدئين في القرن العثرين

\begin{tabular}{|c|c|c|}
\hline سنة التأليف & المؤلف & المقطوعات \\
\hline 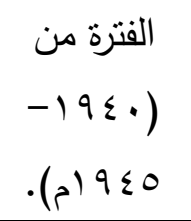 & 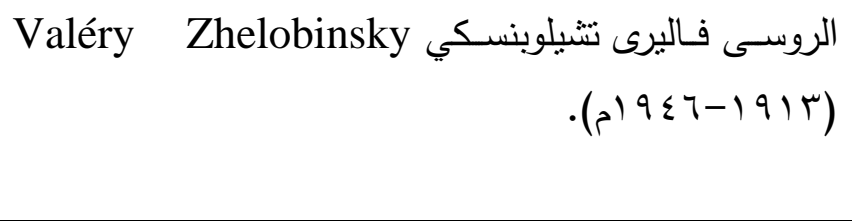 & 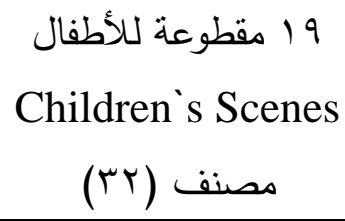 \\
\hline 519V. & 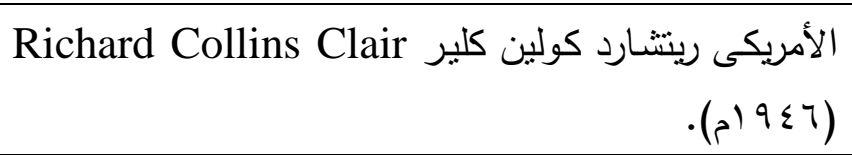 & ^ مقطوعات للأطفال \\
\hline س & 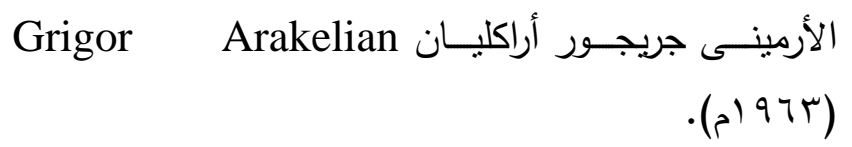 & ^ مقطوعات للأطفال \\
\hline
\end{tabular}

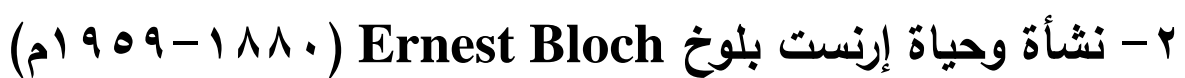

مؤلف ومعلم موسيقى سويسرى المولد وأمريكى الجنسية، كان فناناً بارزاً عرف بأنه أحد أعظم الملحنين السويسريين في النصف الأول من القرن العثرين، ولد في ع بوليو عام ، ـ ام في جنيف Geneva ثانى أكبر مدينة في سويسرا من حيث عدد السكان وهى الجزء الناطق بالفرنسية في سويسرا (1). بدأ إرنست بلوخ العزف على آلة الفيولينة في سن التاسعة من عمره وبدأ التأليف في سن مبكرة، ودرس في كونسيرفتوار بروكسيل Brussels في بلجيكا، حيـ كان مسن بـين أسـاتذته عـازف الفيولينة البلجيكي الثـهير يوجينى يساى Eugène Ysaÿe (10^ ا - اسو (م)، وفي الفترة من عام ( . . 1 - 1 ـ9 (م) إنتقل إرنست بلوخ إلى ألمانيا حيث درس التأليف الموسيقى على يد المؤلف

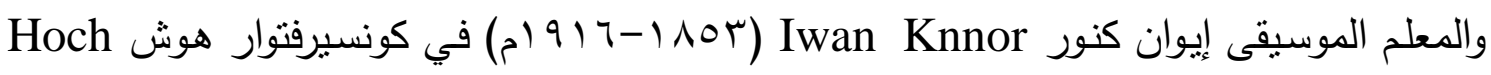
في فرانكفورت Frankfurt بألمانيا، وفي عام ب • 9 ام سافر إرنست بلوخ إلى باريس ثم عاد إلى إنى جنيف، وفي عام 7 ام (م إستقر في الولايات المتحدة الأمريكية (r). وفي عام VI ا (م كان إرنست بلوخ أول معلم للتأليف الموسيقى في مدرسـة مـان للموسيقى Mannes School of Music وهو المنصب الذى شغله لمدة ثلاث سنوات، وفي ديسمبر من من

${ }^{(1)}$ Sadie, Stanly: "The New Grove Dictionary of Music and Musician", Macmillan Publishers Limited, USA, 2001, P.289.

(2) Ernest Bloch: "Ernest Bloch: biography and comment", Michigan University Publishers, USA, 1925, P.5.

مجلة علوم وفنون الموسيقى - كلية التربية الموسيقية ـ المجلد الر ابع و الأربعون -

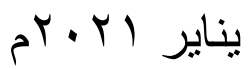


Cleveland Institute of عام • ب 9 ام تم تعيينه أول مدير موسيقى لمعهد كليفلاند للموسيقى Music الذى تم أنشاؤه في تلك الفترة بالولايات المتحدة الأمريكية. وفي عام § 9 ام شغل بلوخ العديد من المناصب الموسيقية التعليمية في الولايـات المتحدة

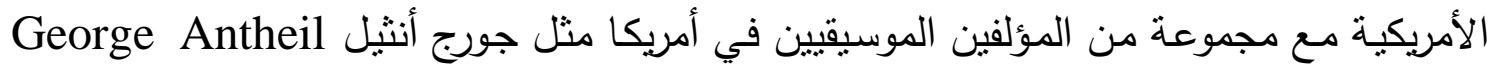

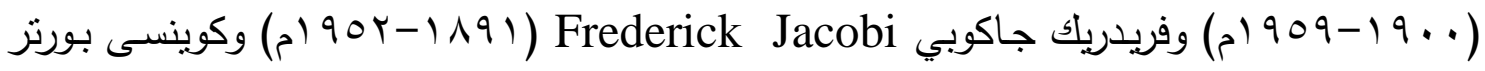

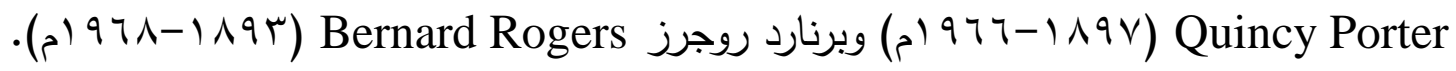

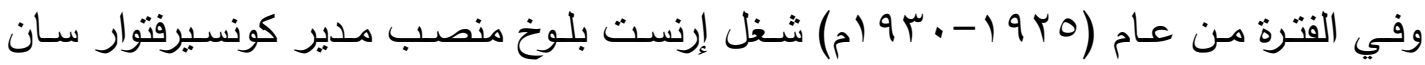
فرانسيسكو San Francisco في كاليفورنيا بالولايات المتحدة الأمريكية بعد أن عينته عازفة البيانو

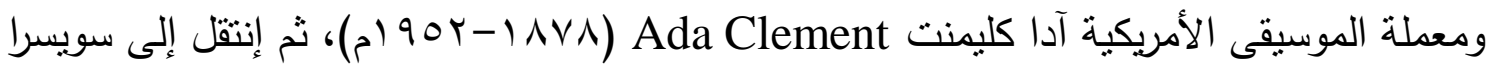

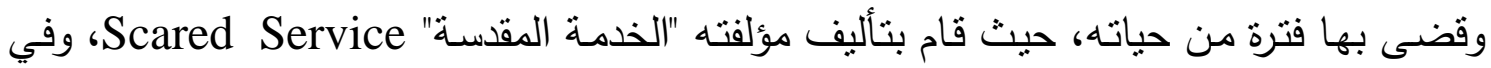
عام 9 9 ام عاد إرنست بلوخ إلى الولايات المتحدة الأمريكية (1).

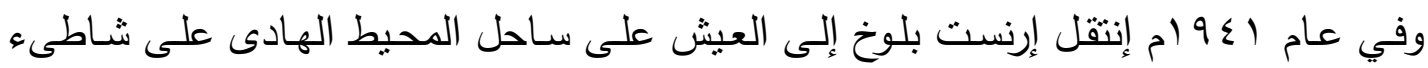

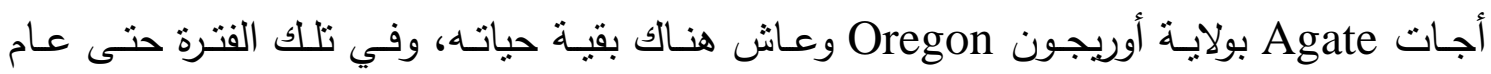

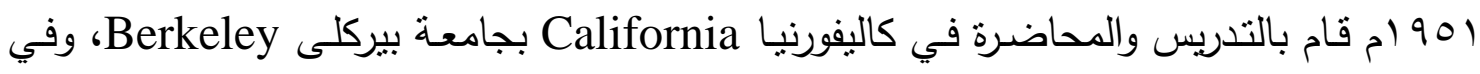

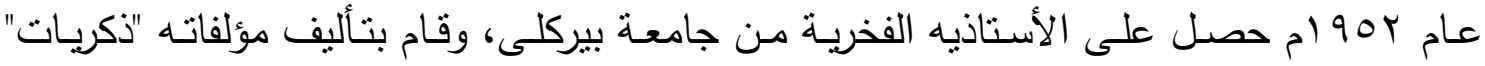
Memorias في نفس العام حزناً على وفاة صديقته آدا كليمنت.

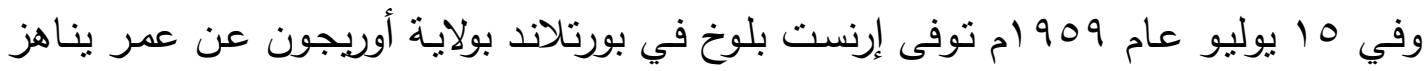

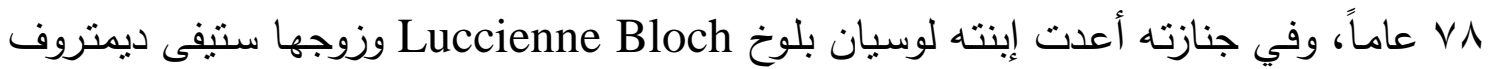
العديد من الأقنعة لإرنست بلوخ، ولم تكن تلك العادة شائعة من قبل أهل

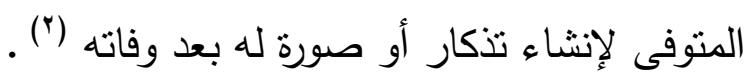

${ }^{(1)}$ www.allMusic.com/biography/Ernest Bloch.

(2) www.ernestblochsociety.com/biography.

مجلة علوم وفنون الموسيقى - كلية التربية الموسيقية ـ المجلد الر ابع والأربعون -

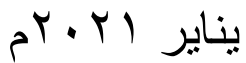


r - مؤلقات إرنست بلوخ لآلة البيانو: (1) جدول رقم (r) مؤلفات إرنست بلوخ لآلة البيانو

\begin{tabular}{|c|c|c|}
\hline سنة التأليف & المصنف & عنوان المؤلفة \\
\hline م)197 & مصنف (r) & Pastoral باستورال \\
\hline ) 199 & مصنف (V) & برسيوس Berceuse \\
\hline ام $1 \wedge 9 V$ & مصنف (r) & $\begin{array}{c}\text { مقطوعتين } \\
\text { Two Pieces }\end{array}$ \\
\hline b) $19 \vee$ & مصنف (ع ()) & مقطوعة "الخرافة" \\
\hline (199V & مصنف (10) & Regrets "مقطوعة "ندم \\
\hline$p^{1} 199$ & مصنف (rr) & منويت Menuet \\
\hline$p^{191 \leq}$ & مصنف (rv) & Ex-Voto "مقطوعة "الناخب السابق \\
\hline blarr & مصنف (ع §)' & Circus "مقطوعات "السيرك \\
\hline larr & مصنف (§ §) & $\begin{array}{c}\text { The Two "مقطوعات "الأخوان بورلينجهام" Brothers } \\
\text { "Burlingham" }\end{array}$ \\
\hline plarr & مصنف (§ §) & $\begin{array}{c}\text { مقطوعات "عظة المرأة" } \\
\text { The Homeliest Woman }\end{array}$ \\
\hline blart & مصنف (T؟) & مقطوعة قصائد البحر Poems of the Sea \\
\hline (9r & مصنف (§^) & Danse Sacrée الرقص المقدس \\
\hline r & مصنف (9) & $\begin{array}{c}\text { Enfantines "عقوعات "الطفولة } \\
\text { (عينة البحث الراهن) }\end{array}$ \\
\hline r & مصنف (Or) & Nirvana "مقطوعات "نيرفانا \\
\hline r & مصنف (Or) & إسكتشات في سيبيا Sketches in Sepia \\
\hline
\end{tabular}

${ }^{(1)}$ Sadie, Stanly: "The New Grove Dictionary of Music and Musician", Macmillan Publishers Limited, USA, 2001, P.290.

مجلة علوم وفنون الموسيقى - كلية التربية الموسبقية ـ المجلد الر ابع و الأربعون -

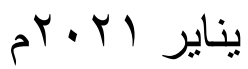


جدول رقم (ץ) مؤلفات إرنست بلوخ لآلة البيانو

\begin{tabular}{|c|c|c|}
\hline سنة التأليف & المصنف & عنوان المؤلفة \\
\hline r & مصنف (بr)' & Prelude بريليود \\
\hline 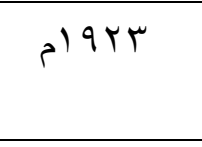 & مصنف (ror) & مقطوعات "دخان في المدينة" \\
\hline (ar & مصنف (ror) & Lucioles "مقطوعات "اليراعات \\
\hline م) & مصنف (79) & Sonata صوناتا \\
\hline م) & مصنف (V) & الرؤى والنبؤات Visions et Prophéties \\
\hline
\end{tabular}

الجزء الثاني: الإطار التطبيقي

أولاً: دراسة مسحية لمقطوعات البيانو للأطفال مصنف (9 ؟) عند إرنست بلوخ من حيث (السلم-

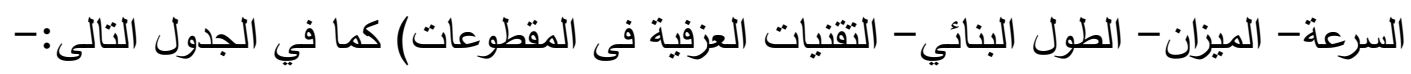

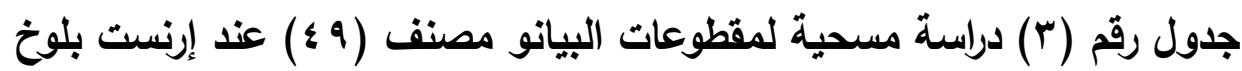

\begin{tabular}{|c|c|c|c|c|c|}
\hline التقتيات العزفية في المقطوعات & الطول البنائي & الميزان & 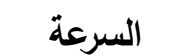 & 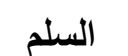 & المقطوعات \\
\hline 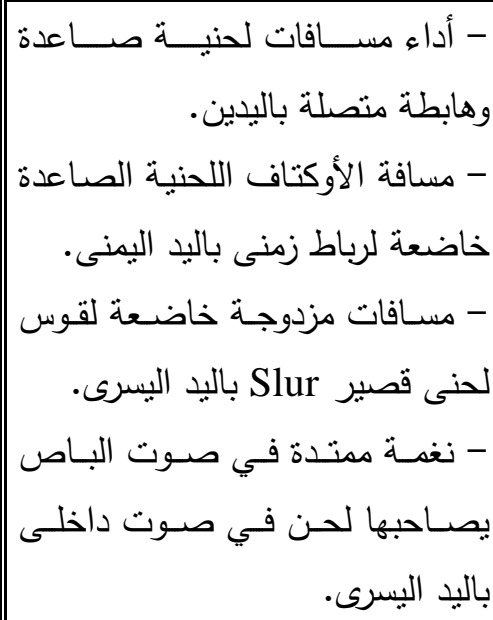 & $\begin{array}{c}r V \\
\text { مازورة }\end{array}$ & $\begin{array}{l}2 \\
2\end{array}$ & $\begin{array}{c}\text { Moderato } \\
\text { منوسط السرعة }\end{array}$ & $\begin{array}{c}\text { الصغير } \\
\text { الغير }\end{array}$ & 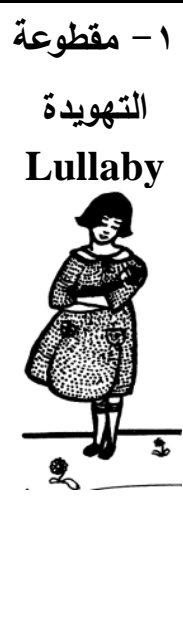 \\
\hline
\end{tabular}

مجلة علوم وفنون الموسيقى - كلية التربية الموسيقية ـ المجلد الرابع و الأربعون -

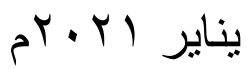


جدول رقم (ץ) دراسة مسحية لمقطوعات البيانو مصنف (9 ؛ ) عند إرنست بلوخ

\begin{tabular}{|c|c|c|c|c|c|}
\hline التقتيات العزفية في المقطوعات & الطول البنائي & الميزان & السرعة & السلم & المقطوعات \\
\hline 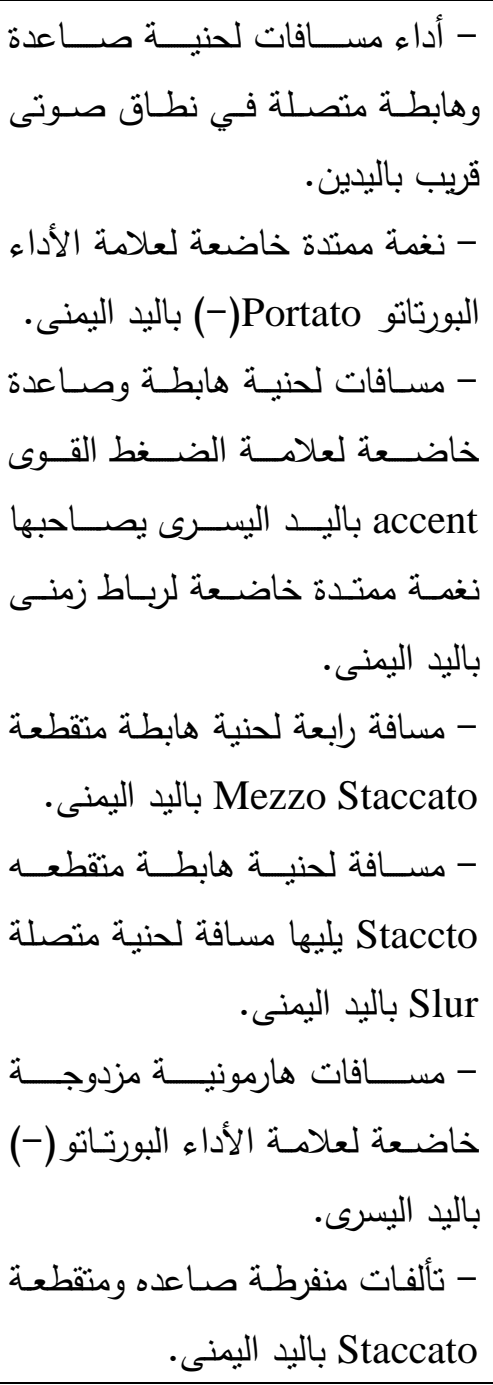 & مازورة & $\begin{array}{l}2 \\
2\end{array}$ & $\begin{array}{l}\text { Allegro } \\
\text { giocoso } \\
\text { سريع بمرح }\end{array}$ & الكبير & $\begin{array}{c}\text { الحفلة - مقطوعة } \\
\text { The } \\
\text { Joyous } \\
\text { Party } \\
\text { السعيدة } \\
\end{array}$ \\
\hline 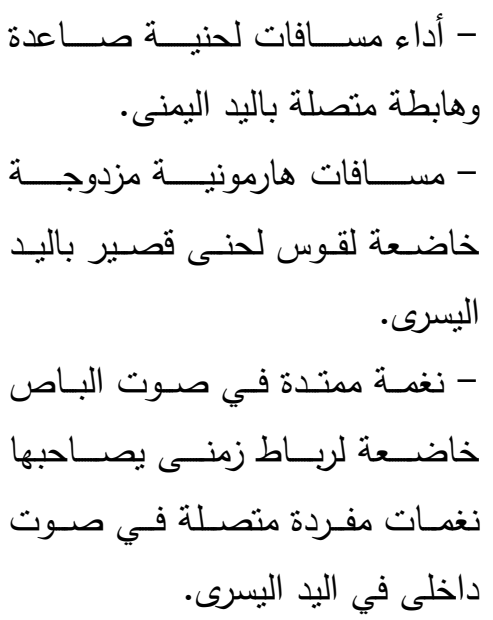 & $\begin{array}{c}\text { مازورة } \\
\text { مازو }\end{array}$ & $\begin{array}{l}2 \\
2\end{array}$ & $\begin{array}{c}\text { Andantino } \\
\text { Espressivo } \\
\text { بطى كعبر }\end{array}$ & صول & $\begin{array}{c}\text { r- مقطوعة الأم } \\
\text { With } \\
\text { Mother }\end{array}$ \\
\hline
\end{tabular}

مجلة علوم وفنون الموسيقى - كلية التزبية الموسيقية ـ المجلد الر ابع و الأربعون -

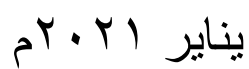


جدول رقم (ץ) دراسة مسحية لمقطوعات البيانو مصنف (9 ؛) عند إرنست بلوخ

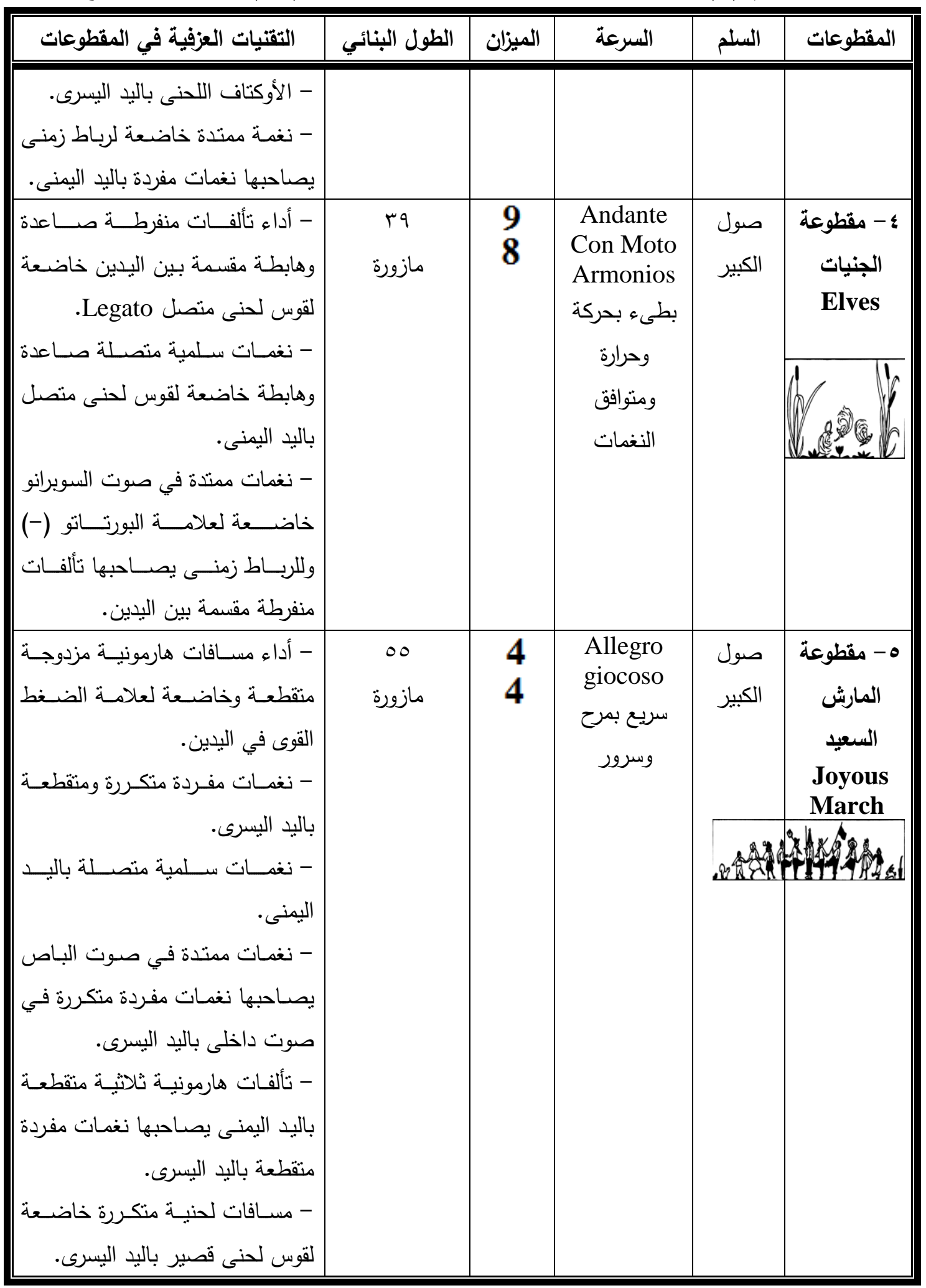

مجلة علوم وفنون الموسيقى - كلية التربية الموسبقية ـ المجلد الر ابع و الأربعون -

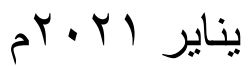


جدول رقم (ץ) دراسة مسحية لمقطوعات البيانو مصنف (9 ؛ ) عند إرنست بلوخ

\begin{tabular}{|c|c|c|c|c|c|}
\hline التقتيات العزفية في المقطوعات & الطول البنائي & الميزان & السرعة & السلم & المقطوعات \\
\hline 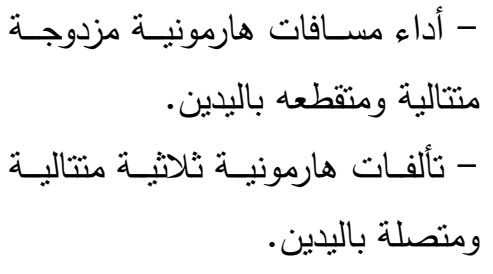 & $\begin{array}{c}\text { مازورة } \\
\text { مازئ }\end{array}$ & $\begin{array}{l}4 \\
4\end{array}$ & $\begin{array}{c}\text { Moderato } \\
\text { متوسطة السرعة }\end{array}$ & الصغير & צ- مقطوعة \\
\hline 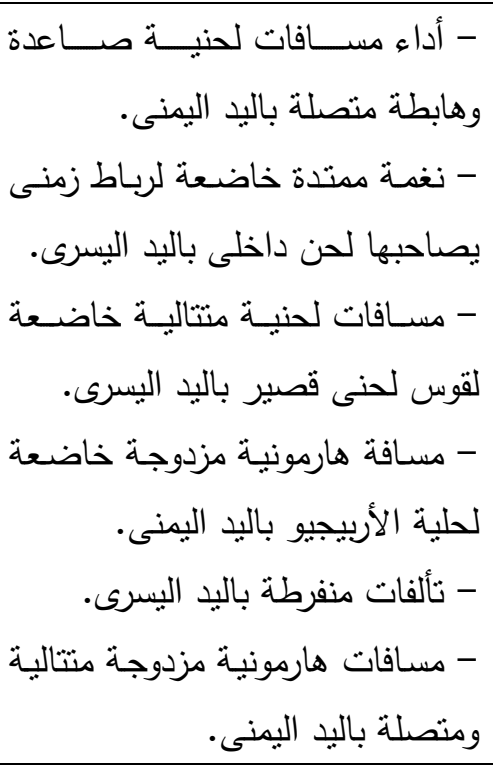 & مازورة & $\begin{array}{l}6 \\
8\end{array}$ & $\begin{array}{l}\text { Moderato } \\
\text { متوسط: السرعة }\end{array}$ & الكبير & مشه ريفى \\
\hline 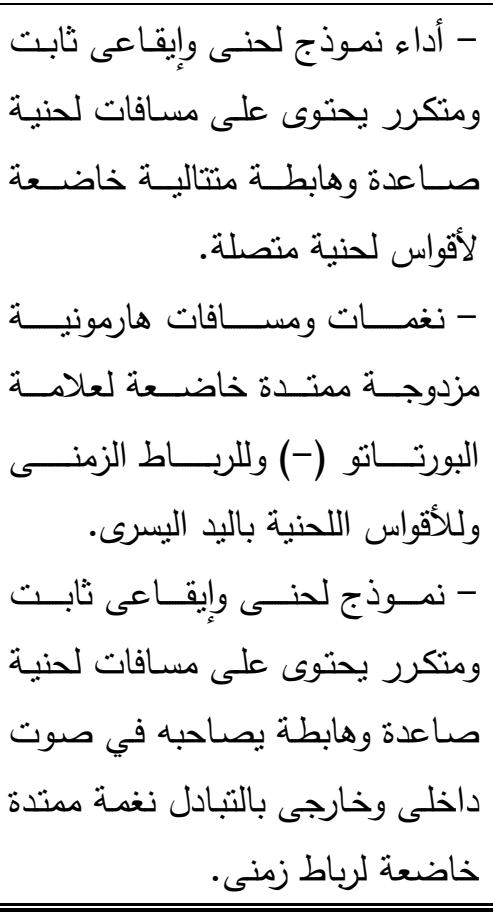 & $\begin{array}{l}\text { مازورة } \\
\text { ما }\end{array}$ & $\begin{array}{l}3 \\
4\end{array}$ & $\begin{array}{c}\text { Andante } \\
\text { Con Moto } \\
\text { بطى بحركة وحرارة }\end{array}$ & الصغير & يوم ممطر \\
\hline
\end{tabular}

مجلة علوم وفنون الموسيقى - كلية التزبية الموسيقية ـ المجلد الر ابع و الأربعون -

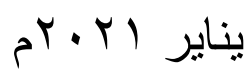


جدول رقم (ץ) دراسة مسحية لمقطوعات البيانو مصنف (9 ؛) عند إرنست بلوخ

\begin{tabular}{|c|c|c|c|c|c|}
\hline التقتيات العزفية في المقطوعات & الطول البنائي & الميزان & 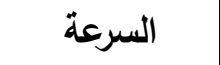 & السلم & المقطوعات \\
\hline 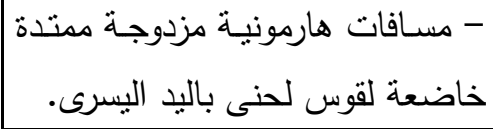 & & & & & \\
\hline 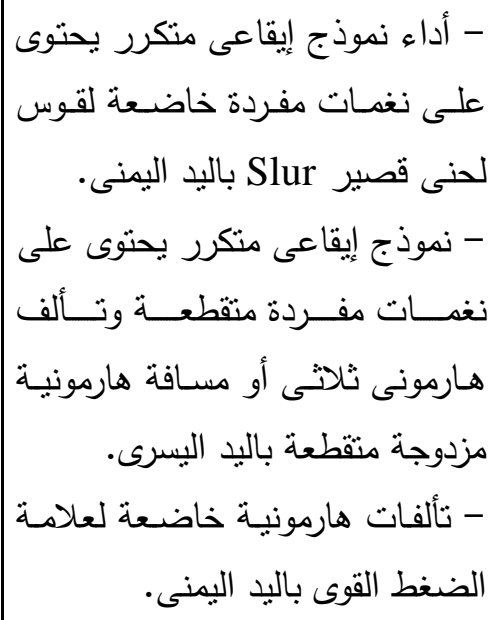 & مازورة & $\begin{array}{l}4 \\
4\end{array}$ & 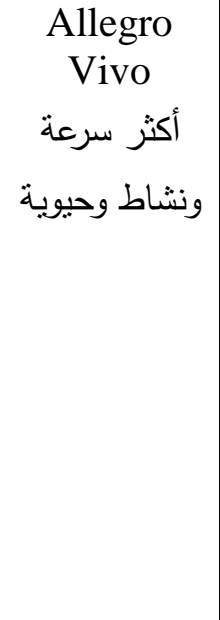 & الكبير & 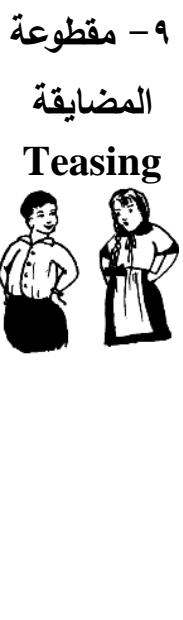 \\
\hline 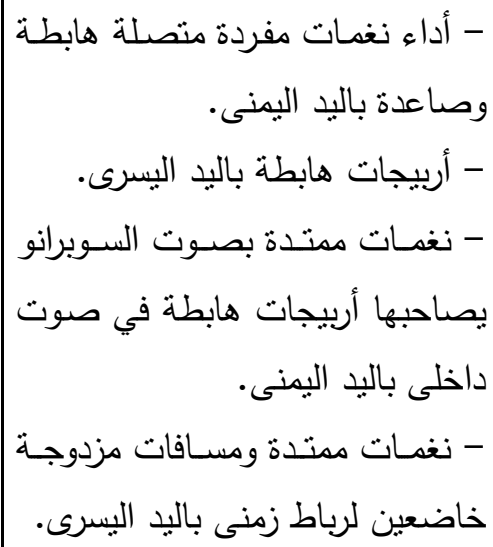 & مازورة & $\begin{array}{l}3 \\
4\end{array}$ & $\begin{array}{c}\text { Andantino } \\
\text { أقل ميلاً من من } \\
\text { Andante }\end{array}$ & الكبير & مقطوعة \\
\hline
\end{tabular}

ثانياً: أسباب إختيار عينة البحث:

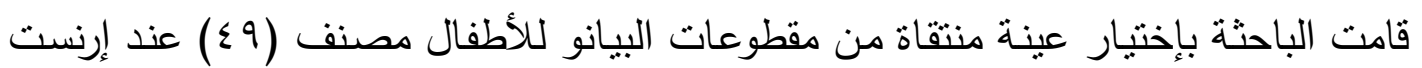

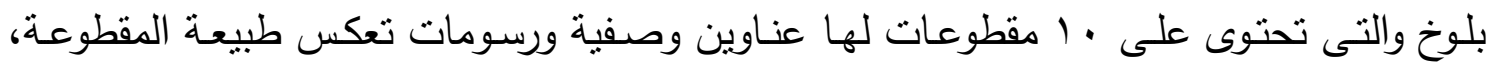
وتتثمل العينة على مقطوعات متتوعة من حيث السلم والسرعة والميزان والطول البنائي والتقنيات

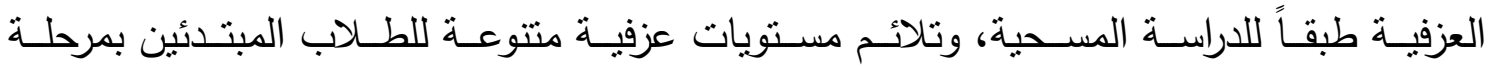

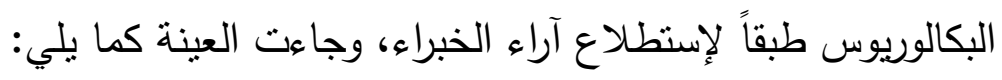

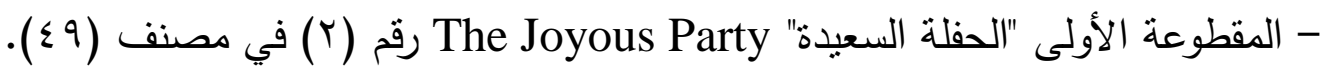

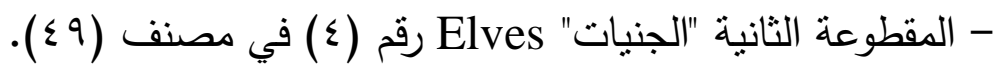

مجلة علوم وفنون الموسيقى - كلية التربية الموسيقية ـ المجلد الر ابع والأربعون -

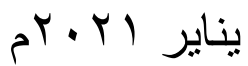




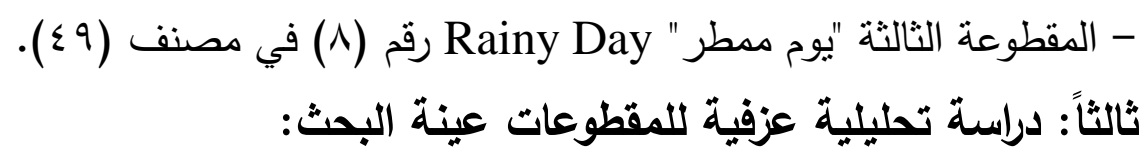

المقطوعة الأولى: الحفلة السعيدة The Joyous Party ( رقم ץ في مصنف 9 ؟ ؛ ) وصف المقطوعة: (تناسب الفرقة الأولى)

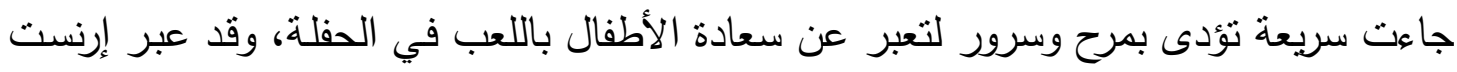

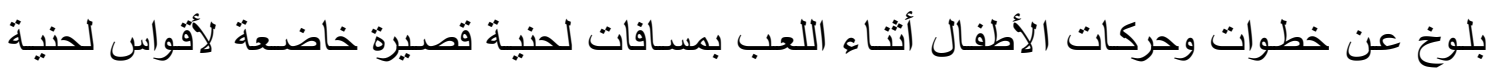

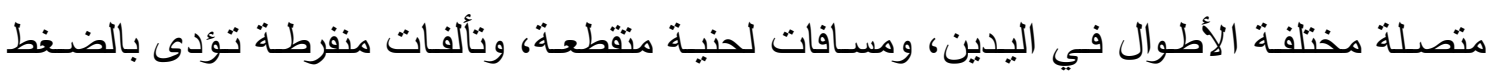
القوى، مع إستخدام نماذج إيقاعية بسيطة في اليدين.

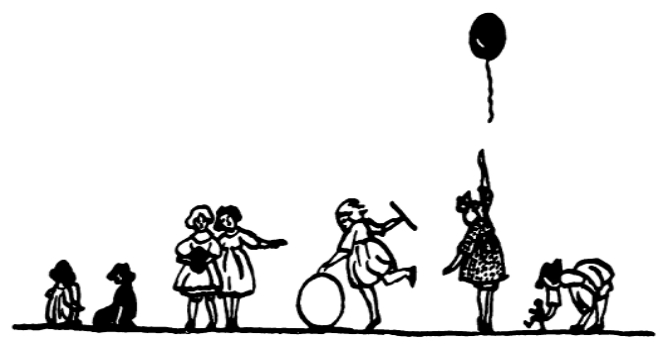

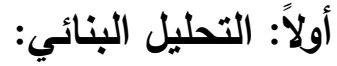

السلم: صول/ك. الميزان: 2 السرعة: Allegro giocoso سريع بمرح وسرور •

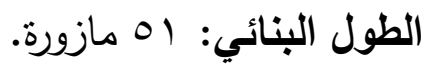
الصيغة: ثنائية مع التكرار بالتصوير A,B,A2,B2

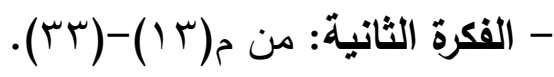

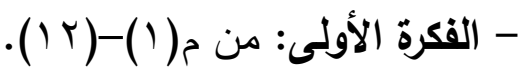

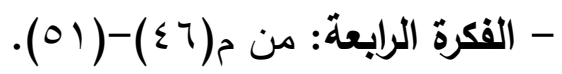

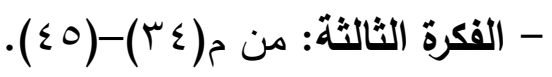

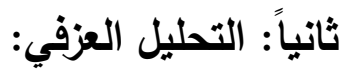
الفكرة الأولى من م(1) (1 ( ) ) تتكون من جملة مطولة.

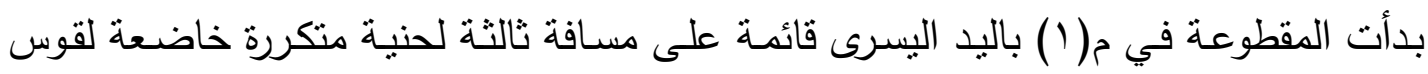

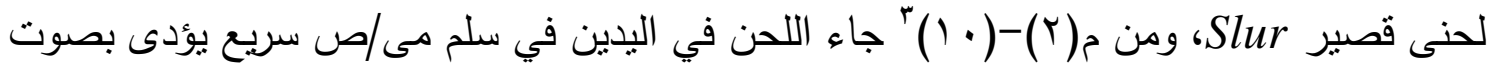

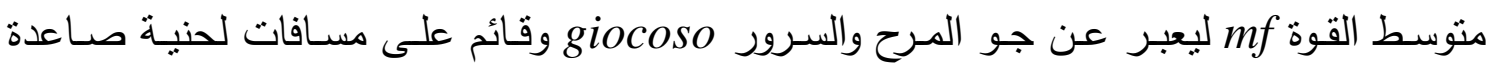
وهابطة خاضعة لأقواس لحنية منصلة Legato مختلفة الأطوال في نطاق صوتى قريب باليدين

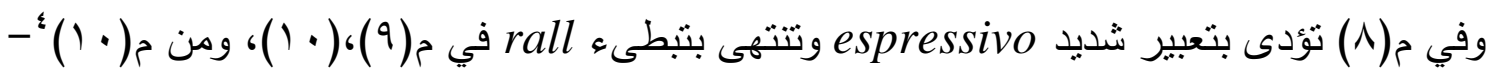

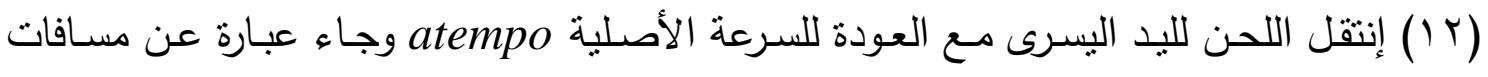

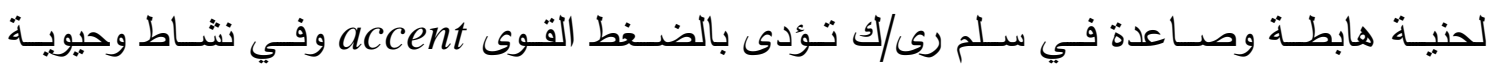
energico

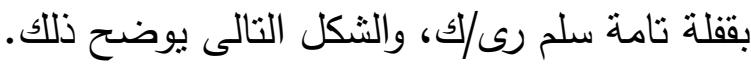

مجلة علوم وفنون الموسيقى - كلية التربية الموسيقية ـ المجلد الر ابع والأربعون -

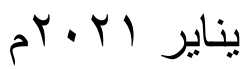



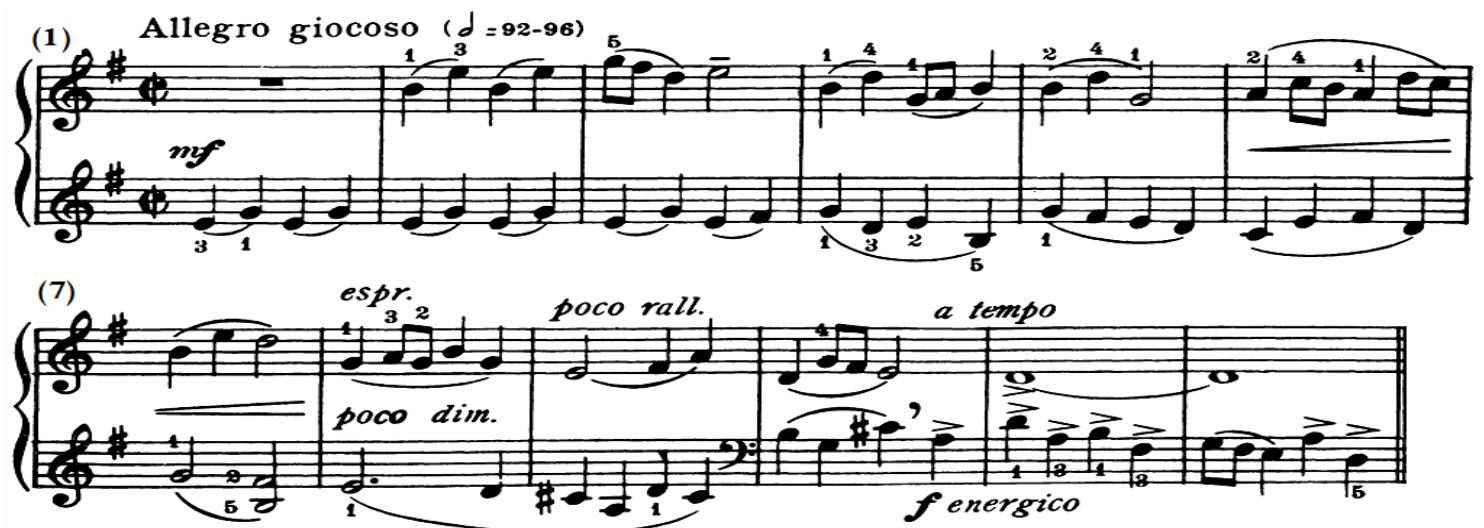

شكل رقم (1)

الفكرة الأولى من م(1)-( ( I ) في مقطوعة الحفلة السعيدة

التقتيات العزفية في الفكرة الأولى من مقطوعة "الحقلة السعيدة" ومتطلبات أدائها: 1 - أداء مسافات لحنية صاعدة وهابطة متصلة في نطاق صوتى قريب باليدين بأقواس لحنية مختلفة، كما جاء من م(1)-( • (1)". ويتطلب أدائهـا الإنتبـاه الثـديد لإقتراب النطـاق الصـوتي بـين اليدين وأهميـة الإلتزام بترقيم الأصسابع بالمدونـة مـع الأداء بتعبير شديد وتبطىء للسرعة في م(9)، ويتطلب أداء القوس اللحنى الإه الطويل Legato والقصير Slur أن تعزف النغدة الأولى بعدق وأكثر وضوحاً في بداية القوس اللحني مع رفع اليد بخفة في نهاية القوس، مع الإنتباه لتغيير مفتاح اليد اليسرى في م( • (). ץ- أداء نغمة ممتدة خاضعة لعلامة الأداء البورتاتو (-) باليد اليمنى، كما جاء في م(ع). ويتطلب أدائها أن تعطى النغدـة الممتدة باليد اليمنى مـدتها الزمنيـة كاملـة وأدائهـا بوضـوح بالضغط بقوة على النغمة المشار إلبها بالعلامة (-). ب- أداء مسافات لحنية هابطة وصـاعدة خاضعة لعلامـة الضغط القوى accent باليد اليسرى يصاحبها نغمة ممتدة خاضعة لرباط زمني باليا اليمنى، كما جاء من م( • ()؛--( ( ). ويتطلب أدائها مراعاة العودة الصحيحة للسرعة الأصلية والضغط بقوة على المسافات اللحنية باليد اليسرى والضغط بقوة على نغمة (رى) باليد اليمنى للحفاظ على إستمرار الصوت.

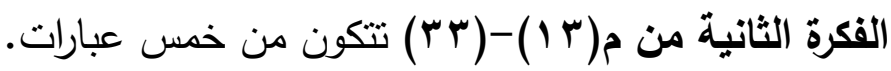

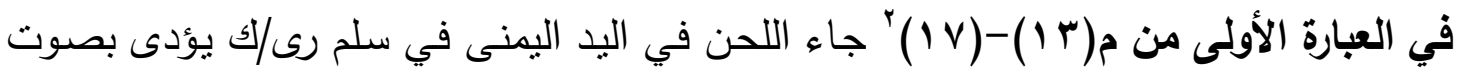
منخفض p قائم على مسافة رابعة لحنية هابطة متقطعة Mezzo Staccato يليها مسافات لحنية متصلة Legato ويصاحبها باليد اليسرى مسافة رابعة لحنيـة هابطة متصلة متكررة مع إستخدام

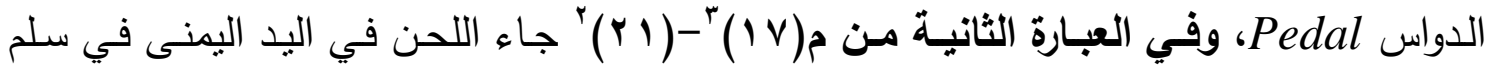
مجلة علوم وفنون الموسيقى - كلية التربية الموسيقية ـ المجلد الر ابع والأربعون -

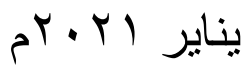


رى/ك، رى/ص يـؤدى بصـوت قـوى f قـائم على مسـافات لحنيــة هابطــة وصــاعدة منقطعــة

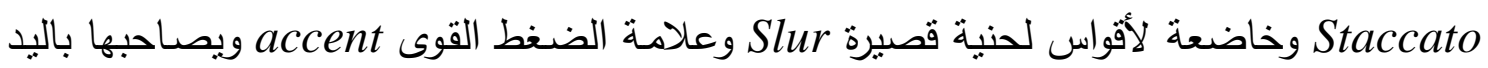

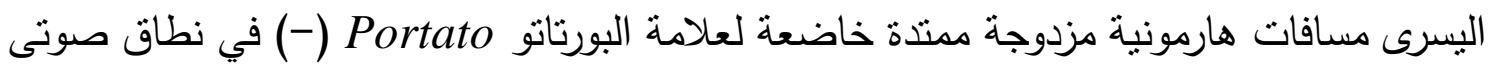

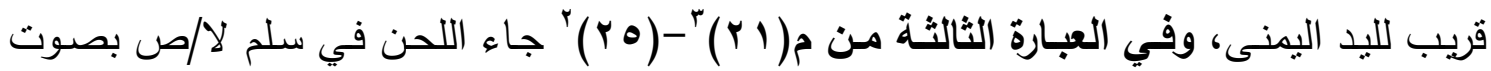
قوى مفاجى f subito قائم على مسافات لحنية هابطة وصاعدة متقطعه خاضعة لعلامة الضغط

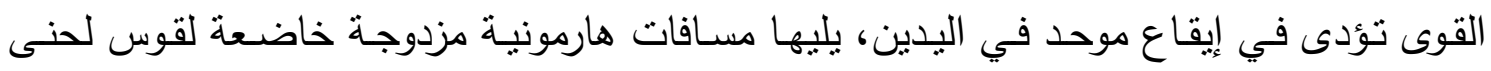

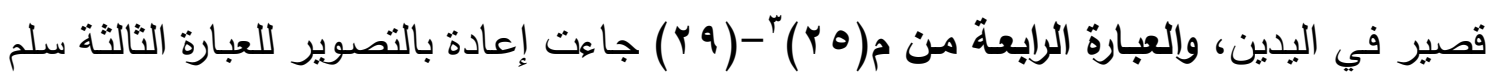

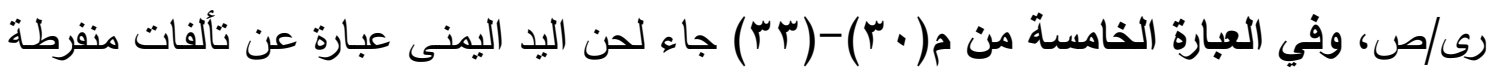

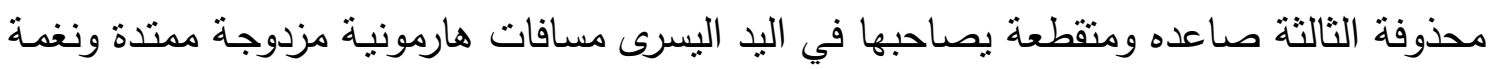

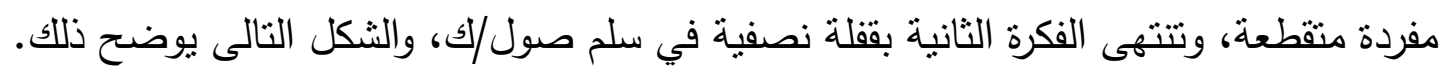
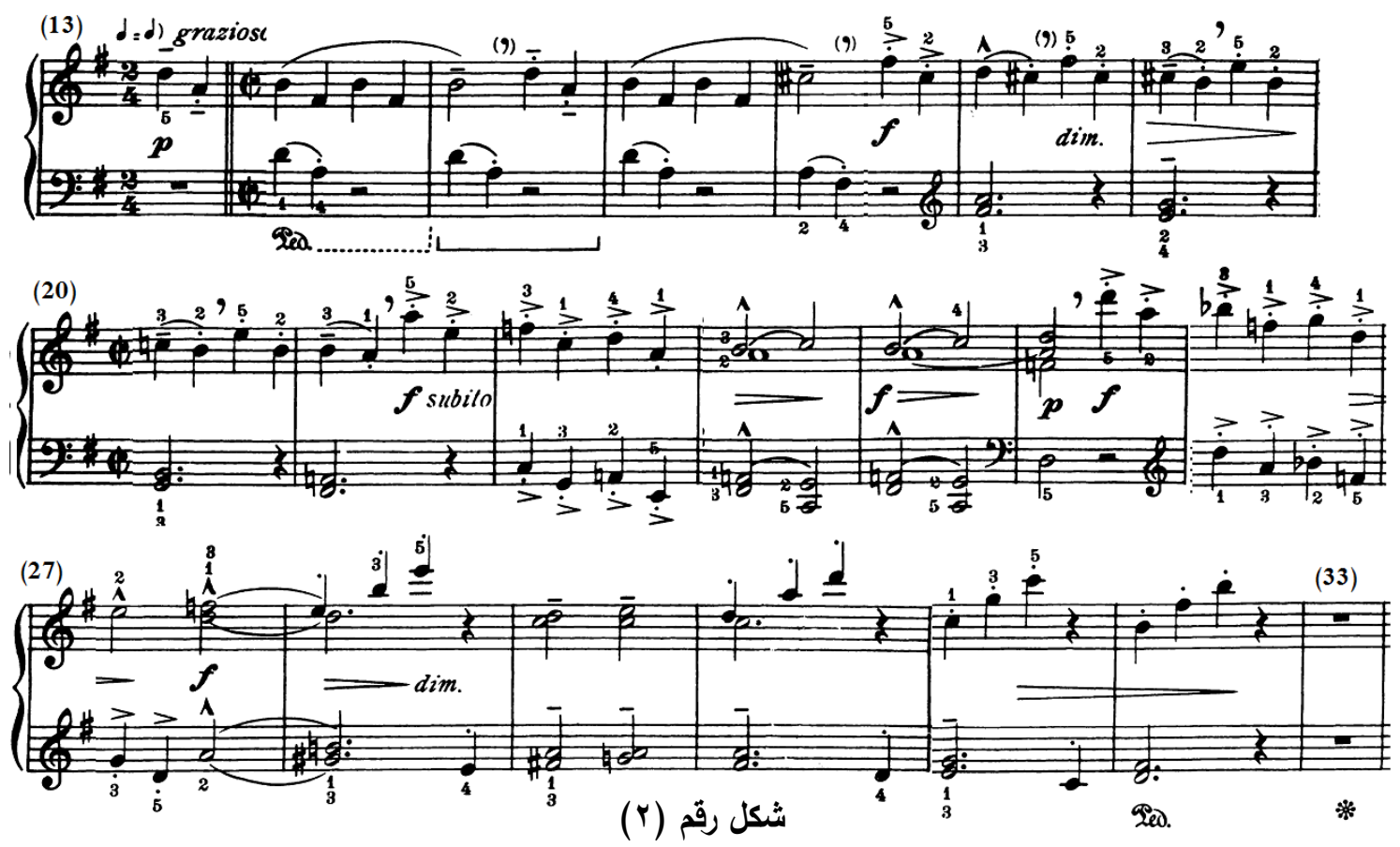

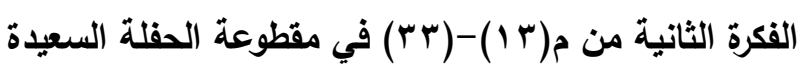

التقتيات العزفية في الفكرة الثانية من مقطوعة "الحفلة السعيدة" ومتطلبات أدائها:

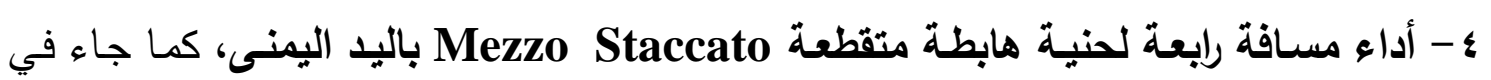
.$(10)(14)^{(1)}$ ويتطلب أدائها أن يفصل بين النغنين سكتة قصيرة تعادل ربع قيمتها الزمنية وتأخذ كل نغدة

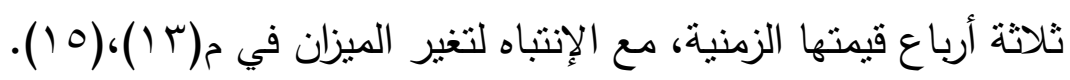

مجلة علوم وفنون الموسيقى - كلية التربية الموسيقية ـ المجلد الرابع و الأربعون -

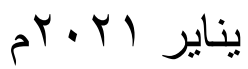


ه- أداء مسافة لحنية هابطة متقطعه Staccto يليها مسافة لحنية منصلة Slur باليد اليمنى،

$$
\text { كما جاء من م(Y) }
$$

وينطلب أدائها إظهار التباين بين الأداء المتقطع والمتصل بحيث أن تؤدى النغمات المنقطعة بإنفصالها عن بعض بخفة، ويفصل بين النغمات سكتة تعادل نصف قيمتها الزمنية وتأخذ النغمات النصف الآخر ، وتؤدى النغمنين الخاضعين لقوس لحنى قصير Slur كما سبق ذكره.

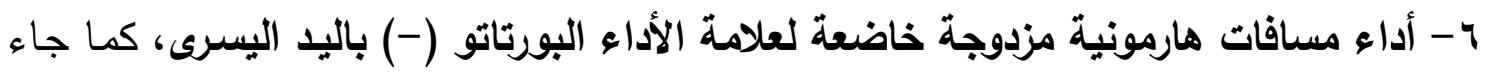

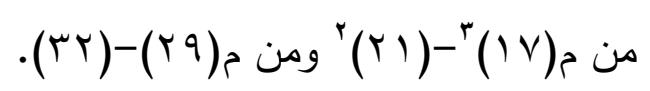

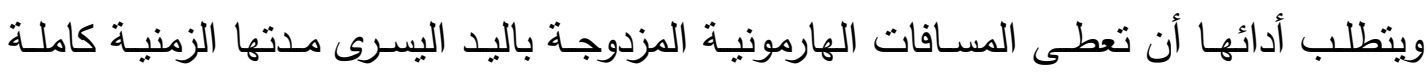

وأدائها كوحدة واحده، مع التركيز الثديد من العازف للإقتراب النطاق الصوتى بين اليدين.

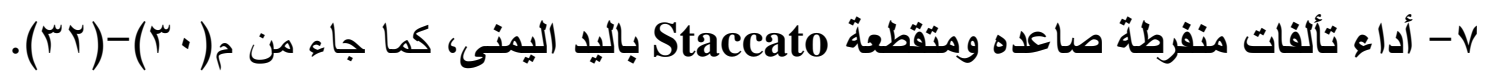

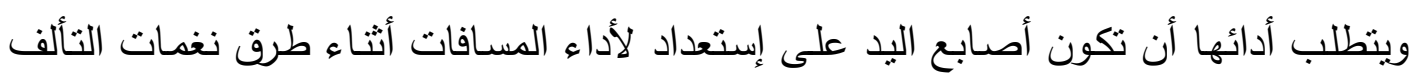
المنفرط على البيانو لكى يكون مستوى قوة اللمس منساوية للنغمات في اليد اليمنى مـع الإلتزام بترقيم الأصابع بالمدونة، ويتطلب أداء العزف المتقطع كما سبق ذكره.

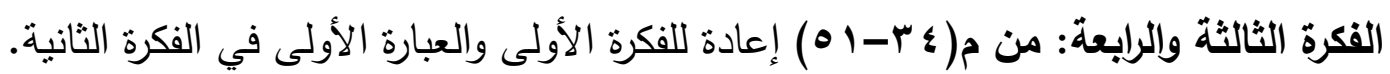

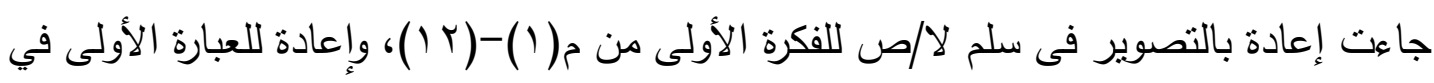

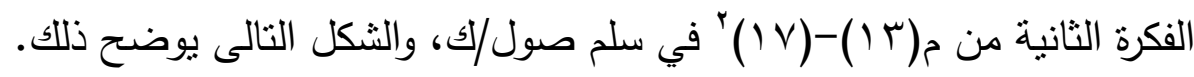
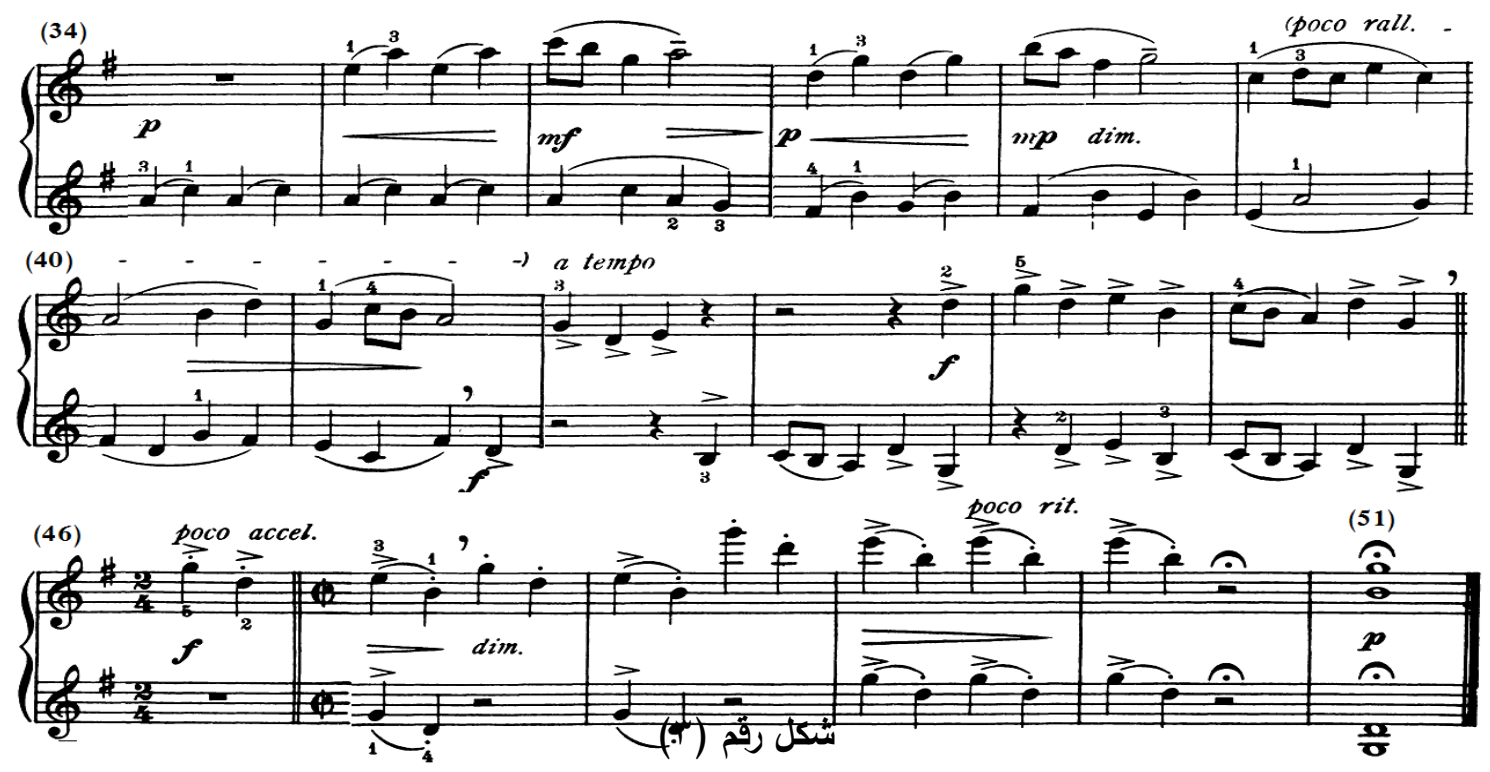

الفكرة الثالثة من م(ع ب)-( ا ه) في مقطوعة الحفلة السعيدة

المقطوعة الثانية: الجنيات Elves (رقم ؛ في مصنف 9 ؛ )

مجلة علوم وفنون الموسيقى - كلية التربية الموسبقية ـ المجلد الر ابع و الأربعون -

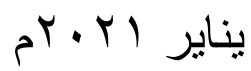


وصف المقطوعة: (تناسب الفرقة التحضيرية) جـاءت بطيئة تؤدى بحركـة وحرارة وبأداء متوافق النغمـات لتعبر عن حركـة الجنيات بين الأغصان وأوراق الثجر في المزارع، وقد عبر إرنست بلوخ عن حركة الجنيات بتألفات منفرطة ولنة

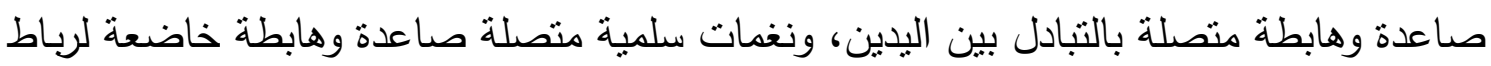
زمنى، مع إستخدام نماذج إيقاعية بسيطة ثابتة ومتكررة ومقسمة بين اليدين.

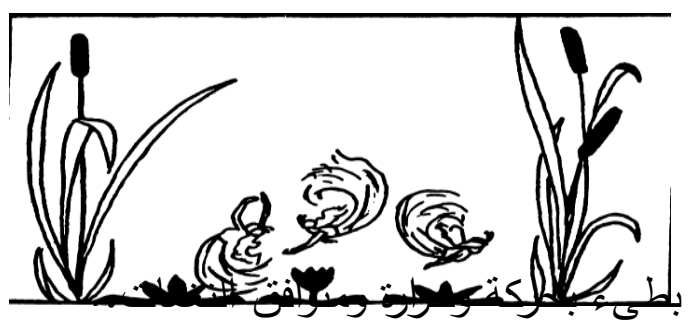

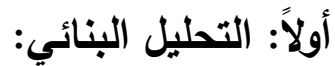

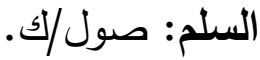
الميزان: 8 السرعة: Andante Con Moto Armonioso

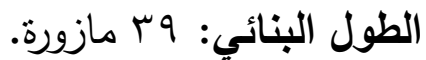
الصيغة: أحادية مع التكرار بالتتويع والتصوير والإعادة كما يلى: - الجملة الأولى: من م(1) - (1) (1).

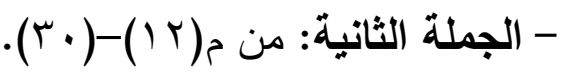

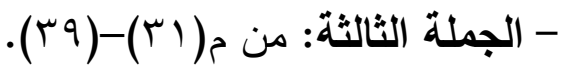
ثانياً: التحليل العزفي: الجملة الأولى من م(1 )-(1 (1) ) جملة مطولة. جاء اللحن من م(1)-(^) مقسم بين اليدين يؤدى بصوت خافت p قائم على تألفات منفرطة صـاعدة وهابطـة بالتبـادل بين اليدين خاضـعة لقوس لحنى متصـل Legato بإستـذام الدواس Pedal وبأداء منوافق النغـات Armonioso، وفي م(V) تؤدى بصوت قوى f ثم تتدرج في باتي الخفوت dim، ومن م(9)-(1) (1) جاء اللحن في اليد اليمنى قائم على ثلاث نغمات سلمية منصلة صاعدة وهابطة خاضعة لرباط زمنى في نهاية كل مازورة ويصاحبها باليد اليسرى ثنلاث نغمات

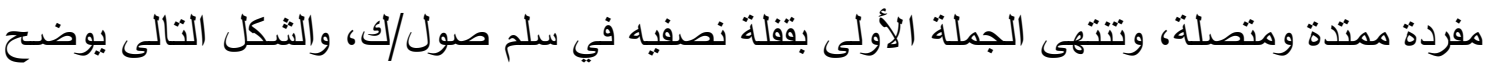
ذلك.

مجلة علوم وفنون الموسيقى - كلية التربية الموسيقية ـ المجلد الر ابع و الأربعون يناير Ir.r 

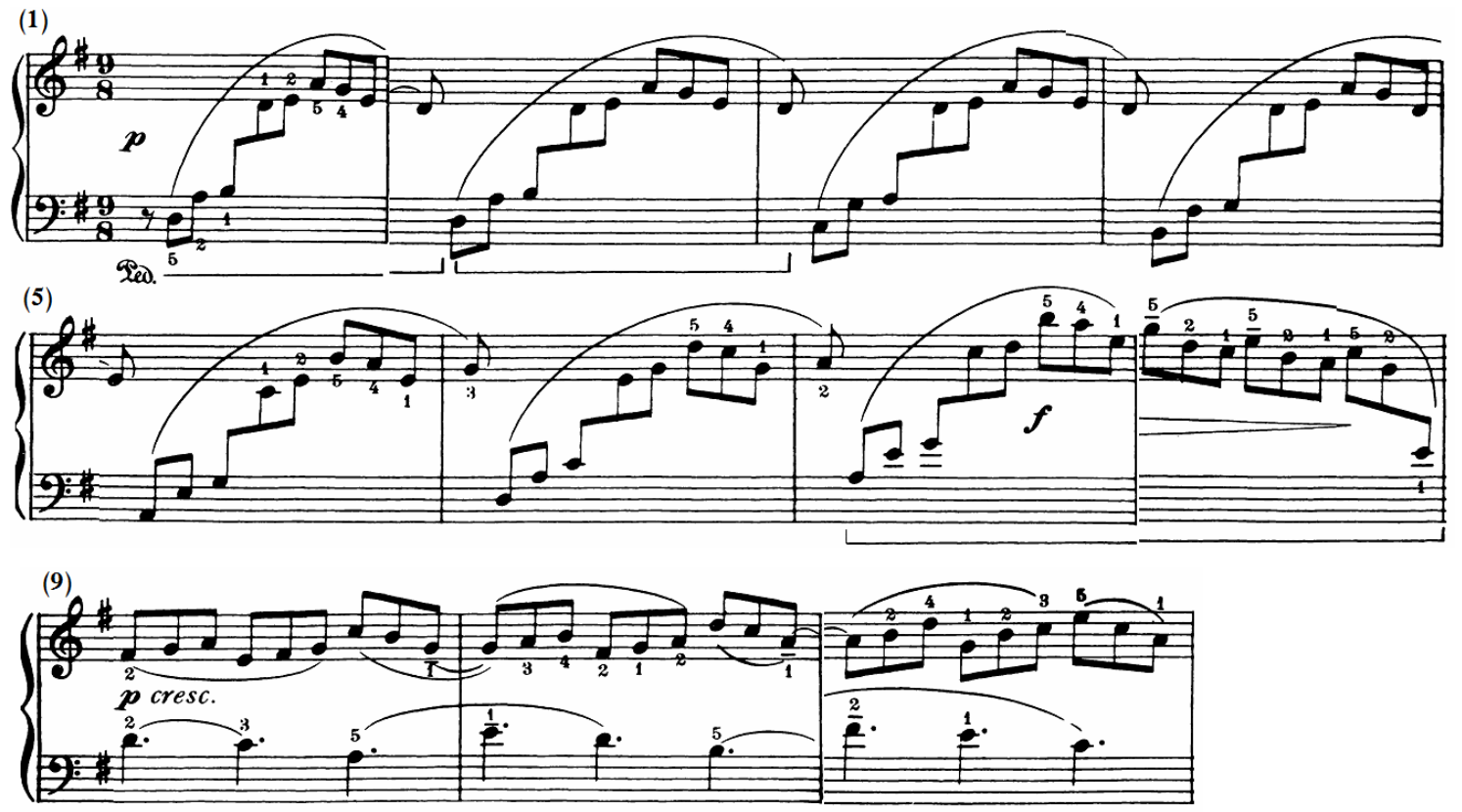

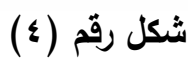

الجملة الأولى من م(1)-(1 (1) في مقطوعة الجنيات

التقنيات العزفية في الجملة الأولى من مقطوعة "الجنيات" ومتطلبات أدائها:

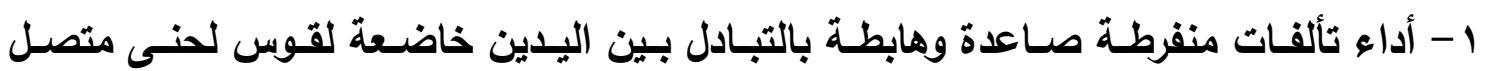
.Legato وينطلب أدائها أن تكون أصابع اليد على إستعداد لأداء المسافات أثناء طرق نغمات التألف

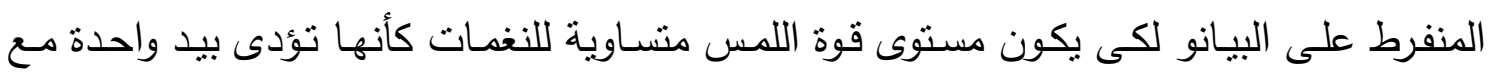
الإلتزام بترقيم الأصابع بالمدونة، وتقترح الباحثة تجميع نغمات التألفات المنفرطة في اليدين كتألفات

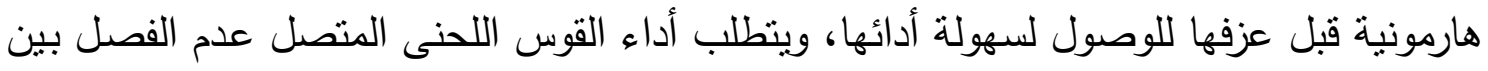
نغمات التألفات المنفرطة الصاعده والهابطة ورفع اليد بخفة فى نهاية القوس الحنى المنصل.

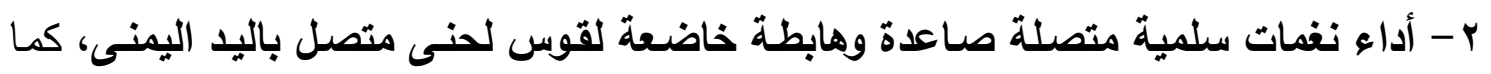

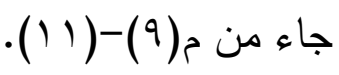

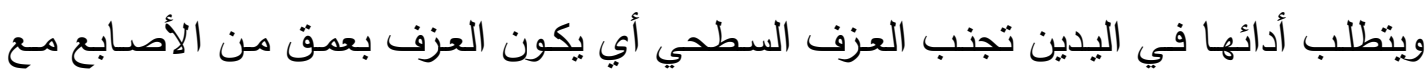

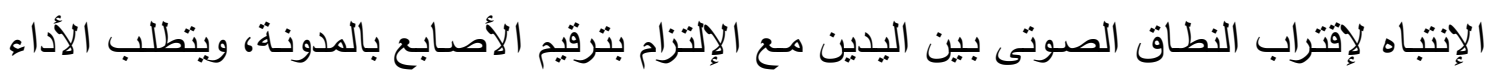

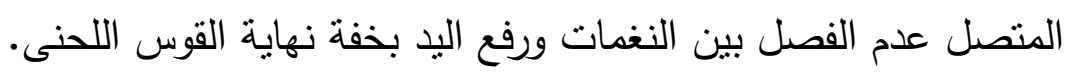

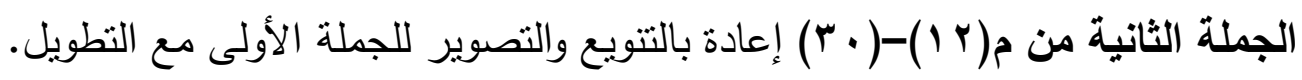

مجلة علوم وفنون الموسيقى - كلية التربية الموسيقية ـ المجلد الرابع والأربعون -

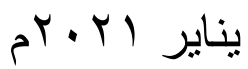


جاء اللحن من م(Y ( )-(Y (Y) في اليد اليمنى يؤدى بصوت قوى f قائم على نغمات ممتدة في صوت السوبرانو وخاضعة للرباط الزمنى ولعلامـة البورتانو espressivo وبطء وتمهل Slentando ويصاحبها باليد اليسرى تألفات منفرطة صاعدة وهابطة

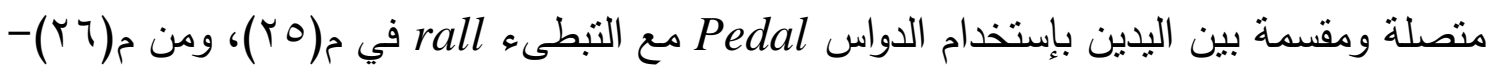

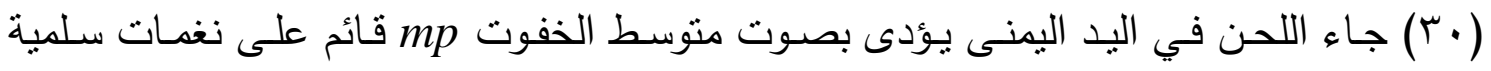

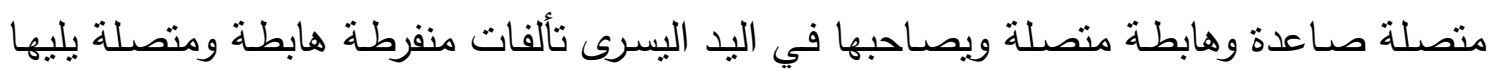

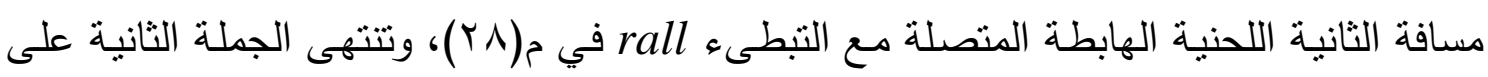
الدرجة الرابعة في سلم صول/ك، والثكل التالى يوضح ذلتك.
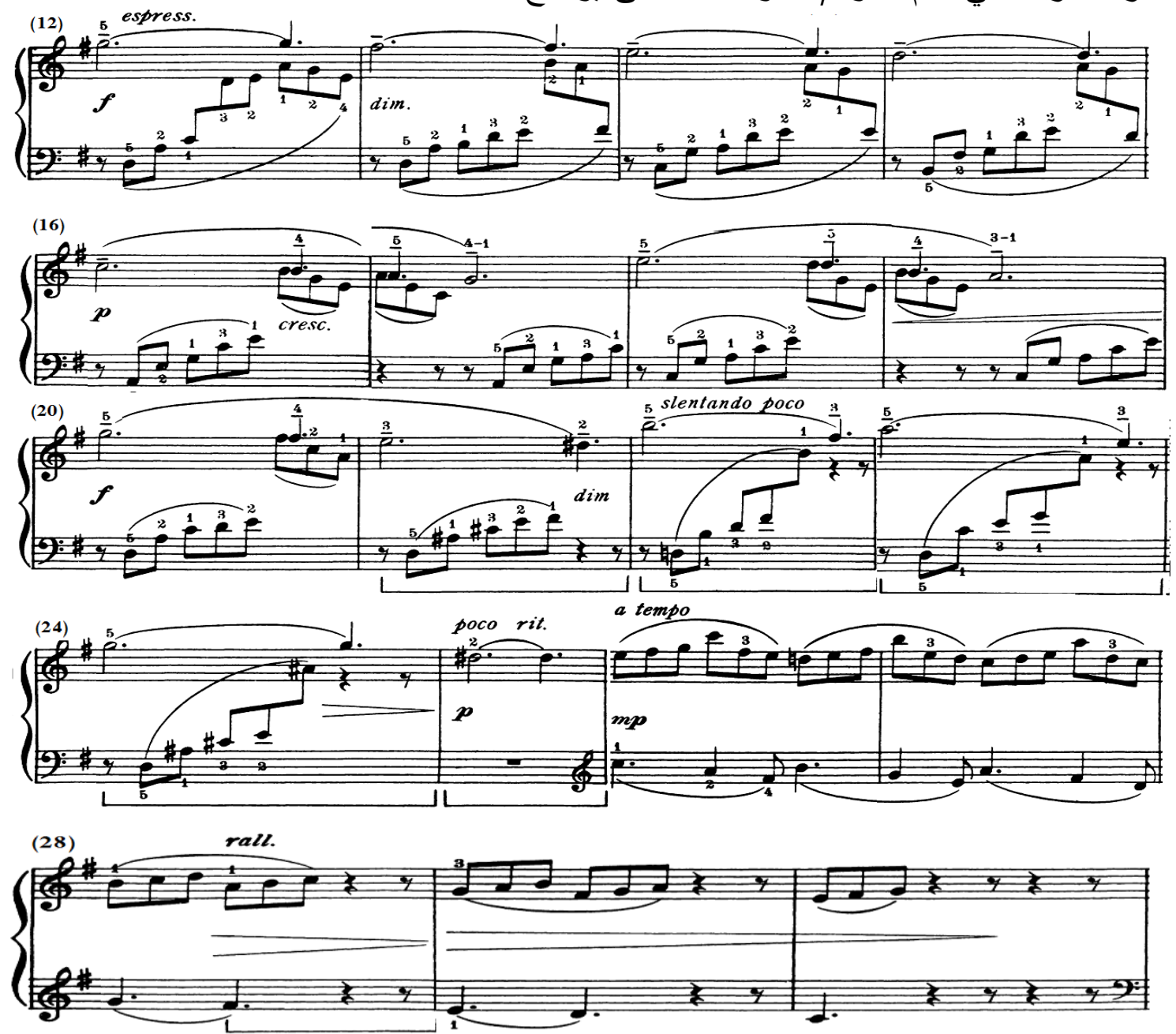

شكل رقم (0)

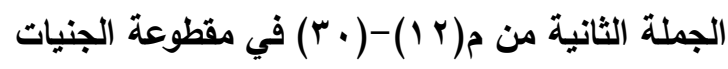

مجلة علوم وفنون الموسيقى - كلية التربية الموسيقية ـ المجلد الر ابع والأربعون -

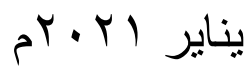


التقنيات العزفية في الجملة الثانية من مقطوعة "الجنيات" ومتطلبات أدائها:

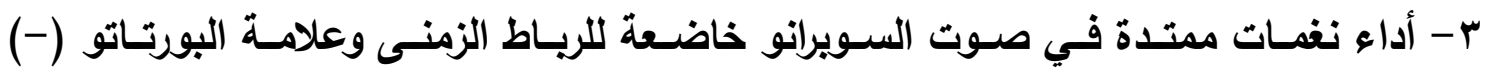

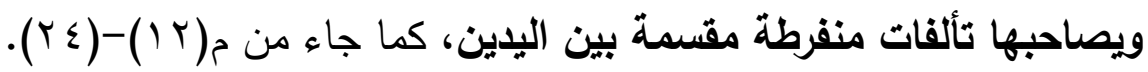

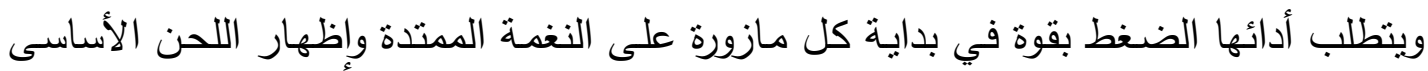

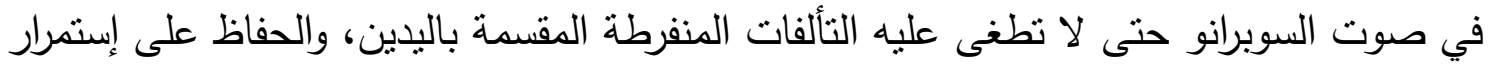
صوت النغمات المندة الخاضعة للرباط الزمنى بإستخدام الدواس، مع مراعاة تثيت النغمة الممتدة عن أداء التألف المنفرط باليد اليمنى.

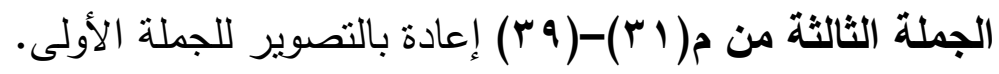

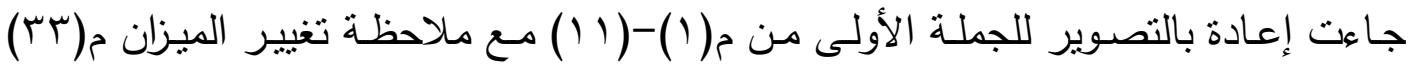

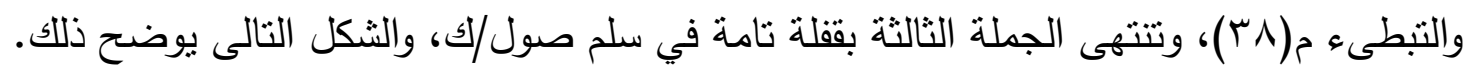

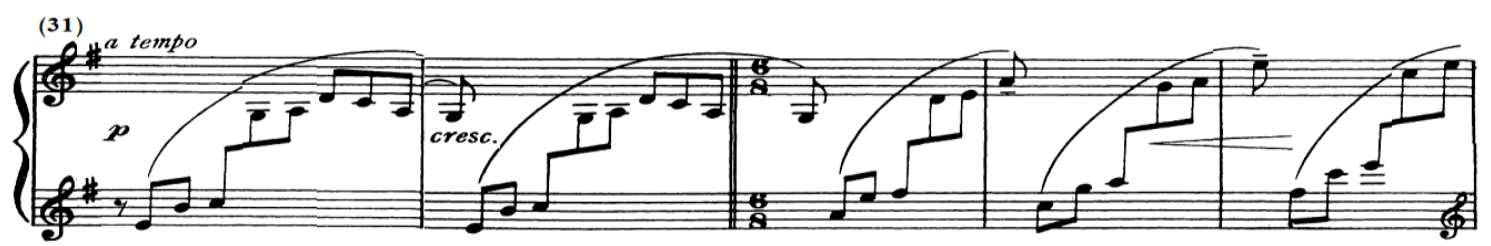

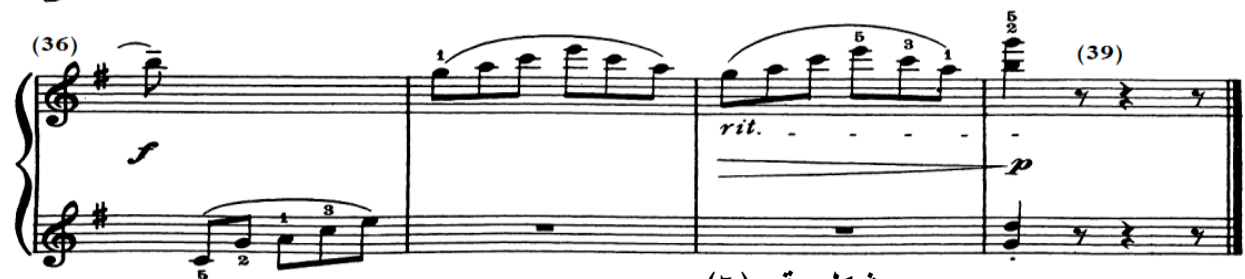

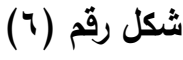

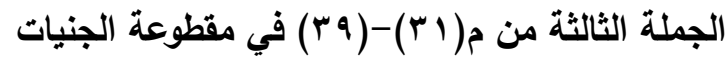

المقطوعة الثالثة: يوم ممطر rainy Day (رقم 1 في مصنف 9 ؛ ) وصف المقطوعة: (تناسب الفرقة التحضيرية) جاءت بطيئة تؤدى بتدفق وحركة وحرارة لتعبر عن سقوط قطرات المطر، وقد عبر إرنست بلوخ عن سقوط المطر بمسافات لحنية قصيرة صاعدة وهابطة متتالية وتزداد المسافات اللحنية لتعبر

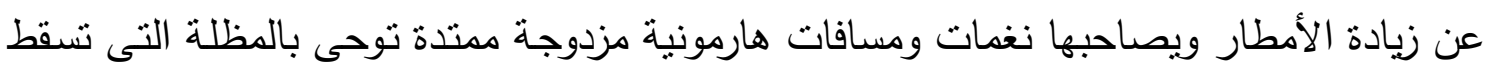

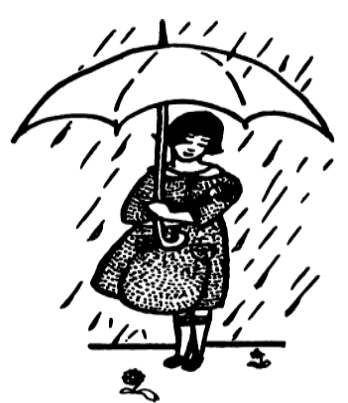
عليها الأمطار ، مع إستخدام نماذج إيقاعية بسيطة وثابتة. أولاً: التحليل البنائي:

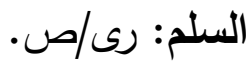
الميزان: - n

مجلة علوم وفنون الموسيقى - كلية التربية الموسيقية ـ المجلد الر ابع والأربعون -

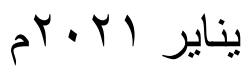


السرعة: Andante Con Moto بطىء يتذفق وحركة وحرارة. الطول البنائي: كاه مازورة. الصيغة: فكرة أحادية مع التكرار بالتتويع والتصوير وتتكون مما يلى:

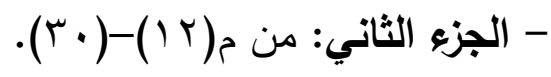

$$
\begin{aligned}
& \text { - الجزء الأول: من م(1) - (Y) - (Y). }
\end{aligned}
$$

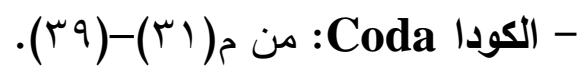

$$
\begin{aligned}
& \text { الجزء الأول من م(1)-(Y^). }
\end{aligned}
$$

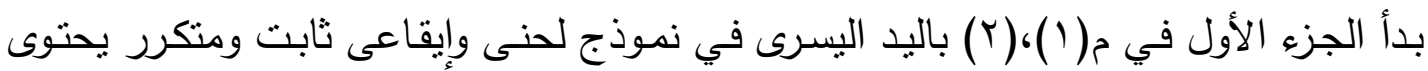

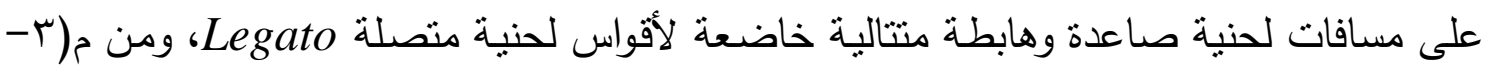
イ جاء لحن عذب dolce في اليد اليسرى قائم على نغمات ممتدة ومسافات هارمونية مزدوجة

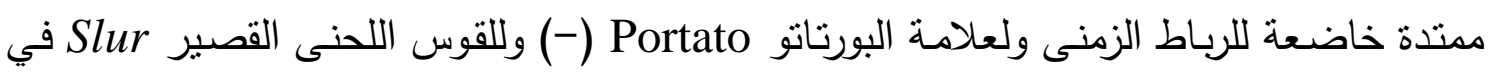

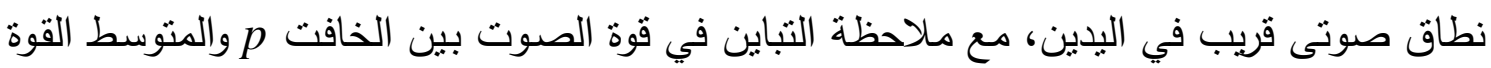

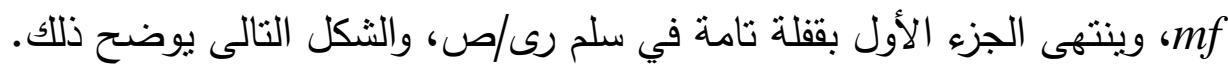
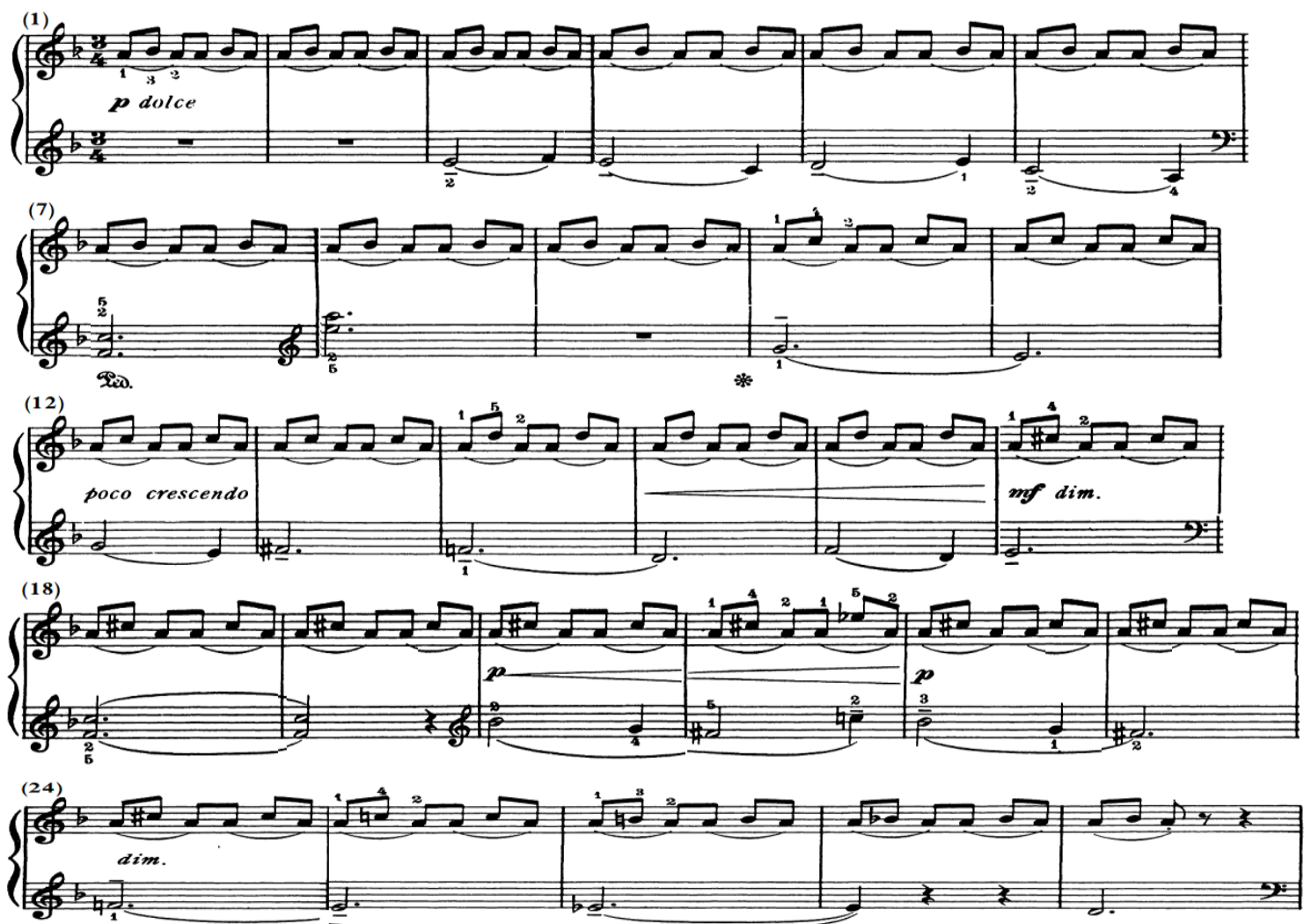

شكل رقم (v)

مجلة علوم وفنون الموسيقى - كلية التزبية الموسيقية ـ المجلد الر ابع والأربعون -

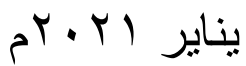




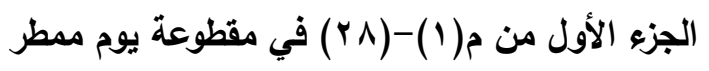

التقنيات العزفية في الجزء الأول في مقطوعة "يوم ممطر" ومتطلبات أدائها: 1- أداء نموذج لحنى وإيقاعى ثابت ومتكرر يحتوى على مسافات لحنية صاعدة وهابطة متتالية خاضعة لأقواس لحنية منصلة Legato باليد اليمنى، كما جاء طوال الجزء الأول. ويتطلب أدائها التركيز لكثرة تغيير المسافات اللحنية وأهمية الإلتزام بترقيم الأصابع بالمدونة الهاهة والإنتباه الثديد لإقتراب النطاق الصوتى بين اليدين، وأداء القوس اللحنى الطويل كما سبق ذكره.

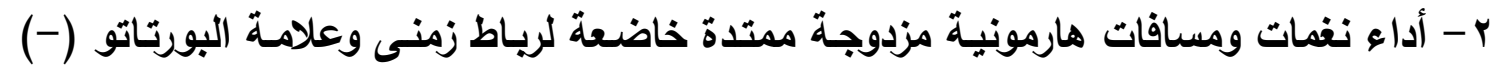
وللأقواس اللحنية القصيرة Slur باليد اليسرى، كما جاء طوال الجزء الأول.

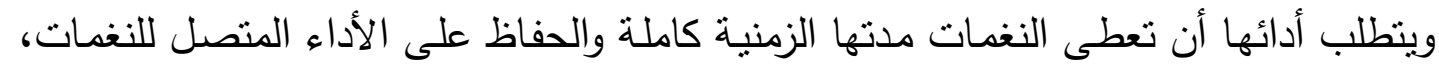

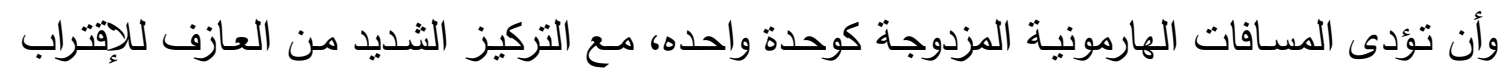
النطاق الصوتى بين اليدين، ومراعاة أداء القوس اللحنى القصير كما سبق ذكره.

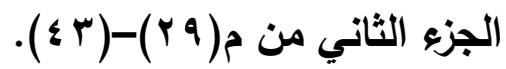
حدث نبادل أدوار بين اليدين في الجزء الثاني حيث إنتقل اللحن القائم على نغمات ومسافات هارمونية مزدوجة ممتدة خاضعة لعلامـة البورتاتو Portato (-) والقوس اللحنى القصير Slur لليد اليمنى ويعاد أوكتاف أعلى، ويصاحبه باليد اليسرى النموذج اللحنى والإيقاعى الثابت والمتكرر

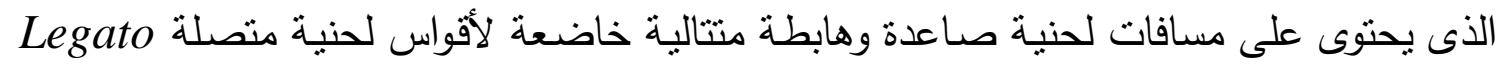

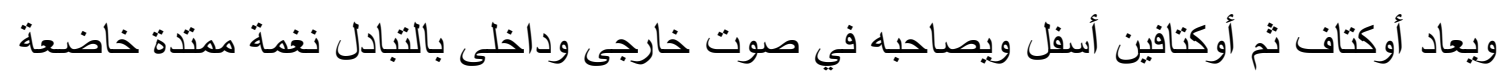
لرباط زمنى، وينتهى الجزء الثاني بقفلة نصفية في سلم رى/ص، والثكل التالى يوضح فئ ذللك.
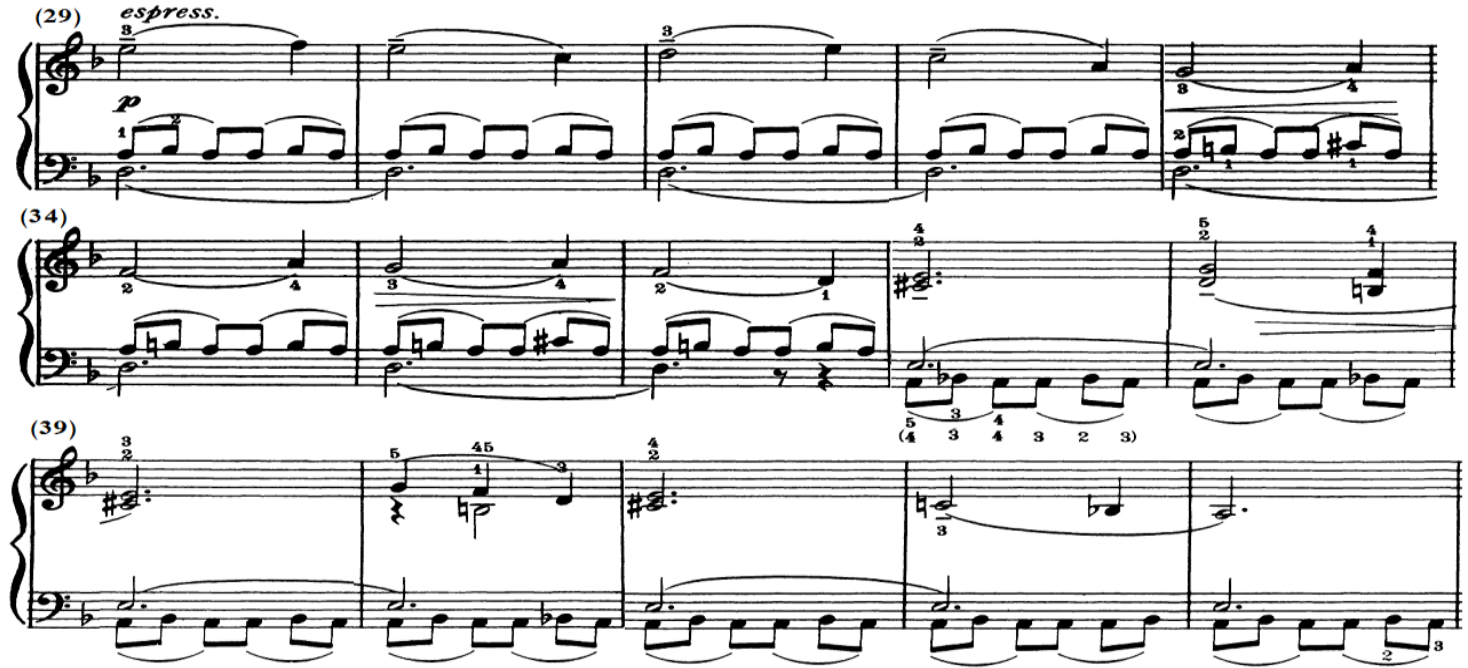

شكل رقم (^)

مجلة علوم وفنون الموسيقى - كلية التربية الموسيقية ـ المجلد الر ابع و الأربعون -

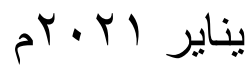




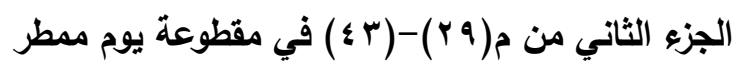

التقنيات العزفية في الجزء الثاني في مقطوعة "يوم ممطر " ومتطلبات أدائها:

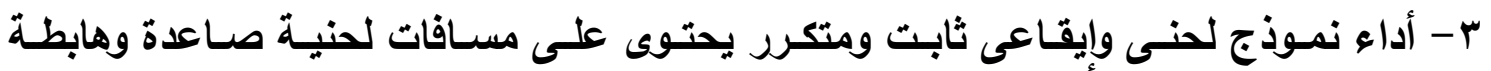
يصاحبه في صوت داخلى وخارجى بالتبادل نغمة ممتدة خاضعة لرياط زمنس باليد اليسرى، كما

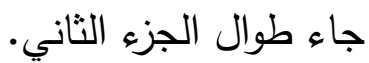
وينطلب أدائها الحفاظ على تثبيت النغمـة المثتدة في الصوت الداخلى والخـارجى بإستخدام الدواس، مع مراعاة إظهار المسافات اللحنية وأن لا تطغى عليها النغمة الممتدة.

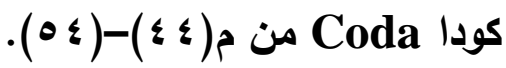
بدأت الكودا في اليد اليسرى مأخوذة من الجزء الأول وقائهـة على مسـافات لحنيـة صـاعدة

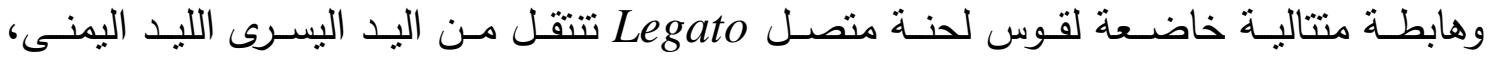
ويصاحبها باليد اليسرى مسافات هارمونية مزدوجـة متصلة وخاضعة لرباط زمنى، مـع ملاحظة

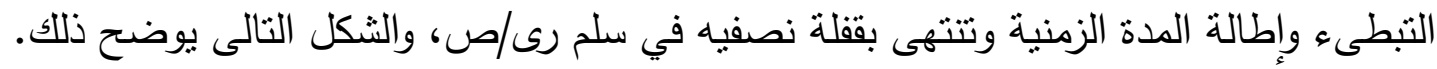

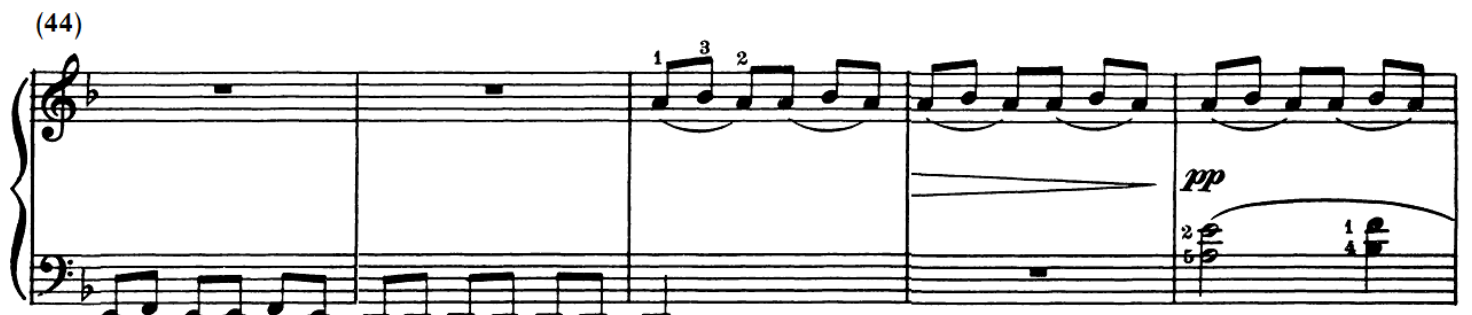

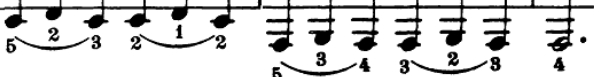

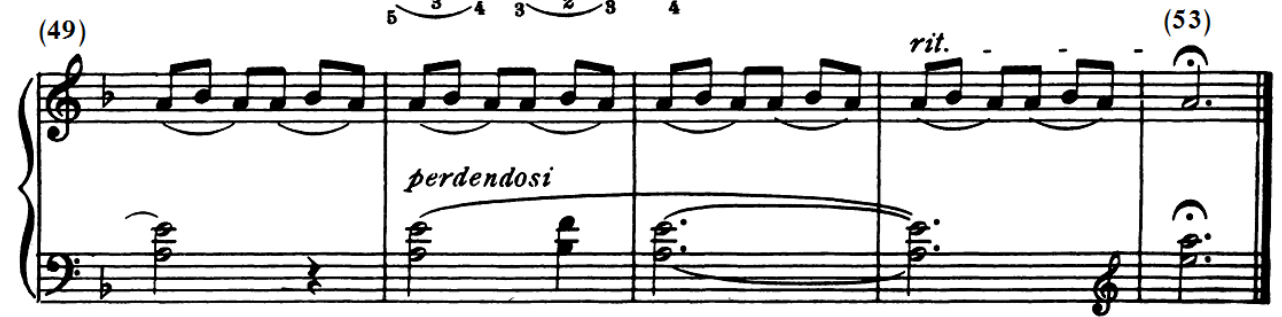

(9) شكل رقم (9) (9)

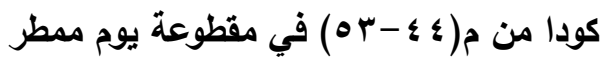

التقتيات العزفية في الكودا من مقطوعة "يوم ممطر" ومتطلبات أدائها:

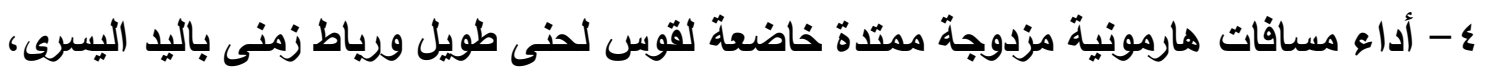

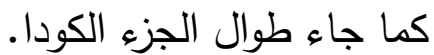

مجلة علوم وفنون الموسيقى - كلية التربية الموسيقية ـ المجلد الر ابع والأربعون -

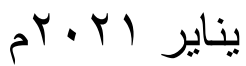


وينطلب أدائها أن تعطى النغمات مدتها الزمنية كاملة والحفاظ على الأداء المتصل للنغمات،

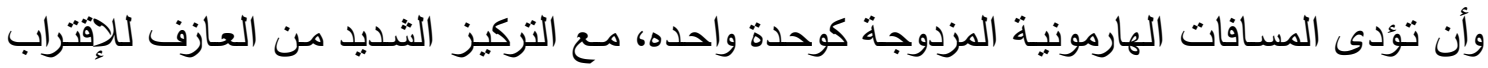
النطاق الصوتى بين اليدين، ومراعاة أداء القوس اللحنى الطويل كما سبق ذكره.

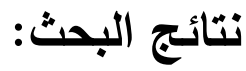

بعد أن قامت الباحثه بالدراسة المسحية لمقطوعات البيانو للأطفال مصنف (9 ؛) عند إرنست بلوخ، والدراسـة التحليلية العزفية لـقطوعات عينـة البحث رقم (؟، ع، ^) وتحديد التقنيات العزفية في مقطوعات عينة البحث وتوضيح منطلبات أدائها كما جاء في الإطار التطبيقي، فقد توصلت ولته

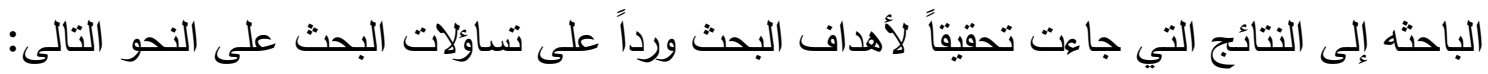
التساؤل الأول:

\section{ما سمات مقطوعات البيانو للأطفال مصنف (9 ؛ ) عند إرنست بلوخ ؟}

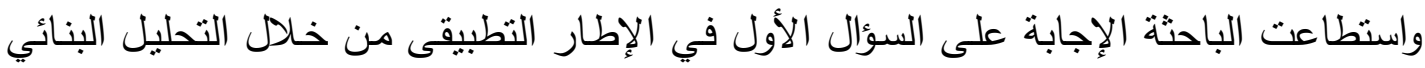

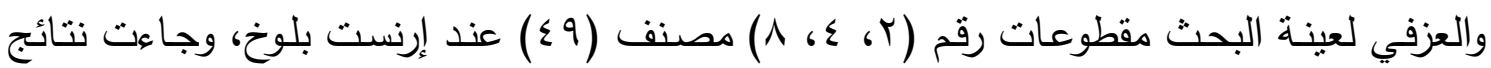
التحليل البنائي والعزفي كما يلى: - التئ 1- إسـتخدم إرنسـت بلـوخ السـلالم كبيـرة والصـيرة مـع الإنتقال للسـلام المجـاورة، حيـث جـاءت

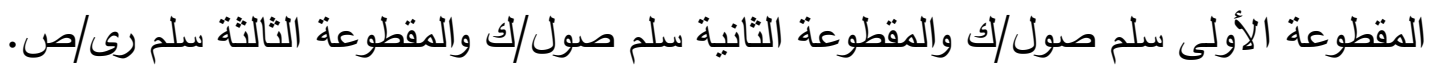
r - تميز كل من المقطوعة الأولى والثانية بتعدد الموازين ولم يتم تغيير الميزان بالمقطوعة الثالثة.

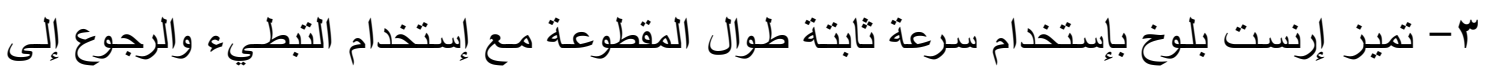
السرعة الأصلية بكثرة، وإستخدام علامة إطالة المدة الزمنية في نهاية المقطوعة الأولى والثانية.

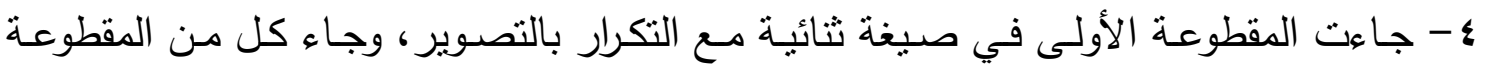

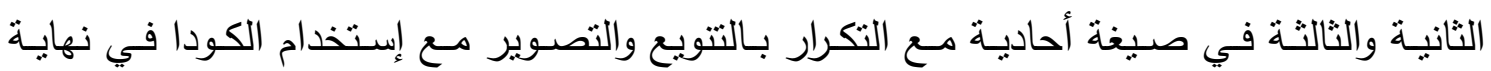

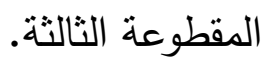
ه- إستخدم إرنست بلوخ في المقطوعة الأولى الألحان المعتمدة على مسـافات لحنية صـاعدة

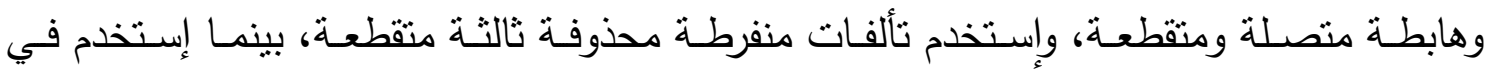
المقطوعة الثانية تألفات منفرطة صـاعدة وهابطة مقسمة بين اليدين، ونغمات ممتدة في صوت الئه

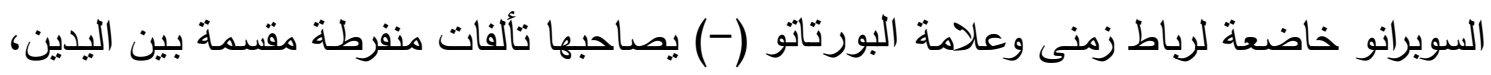

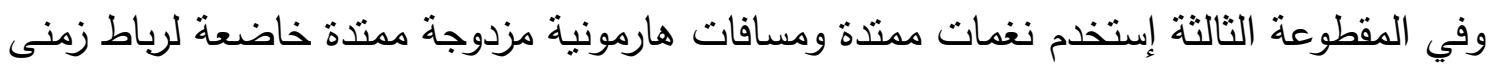

مجلة علوم وفنون الموسيقى - كلية التربية الموسبقية ـ المجلد الر ابع و الأربعون يناير بr.r. 
وعلامة البورتاتو (-) ولرباط زمنى وقوس لحنى قصير Slur، ونغمات ومسافات هارمونية مزدوجة

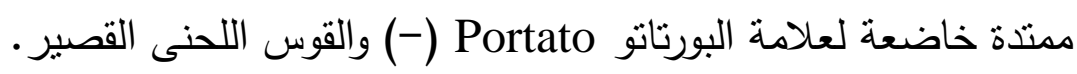

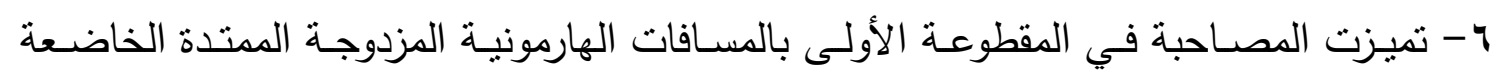

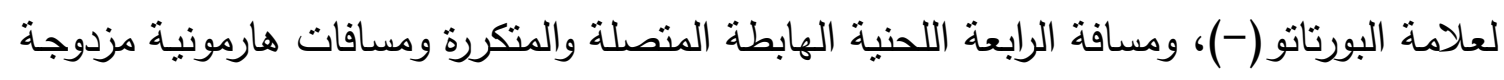

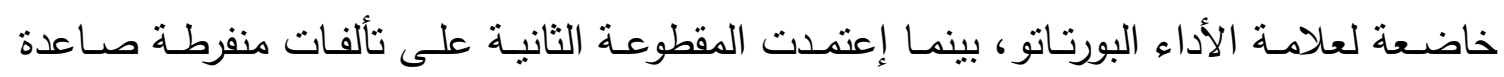

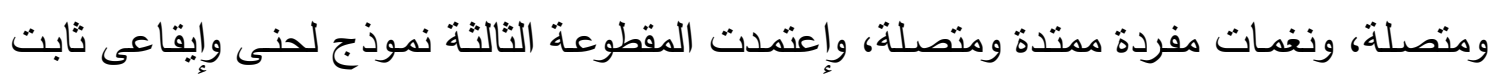

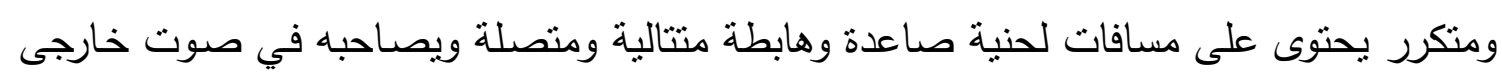

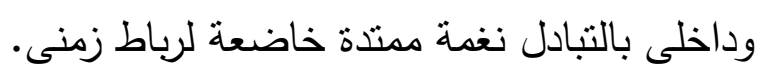
V- تميزت المقطوعات الثثلاثة بنماذج إيقاعية بسيطة في اليدين، وتميزت لثياد المقطوعة الأولى بأداء إيقاع موحد في اليدين. 1- تميزت المقطوعات الأولى بكثرة إستخدام علامة الضغط القوى accent وعلامة البورتاتو (-)،

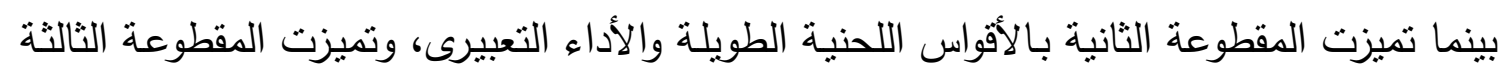
بإستخدام الرباط الزمنى والأقواس اللحنية القصيرة.

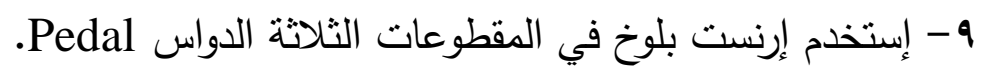

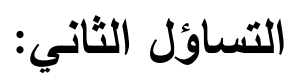

ما المتطلبات الأدائية للتقتيات العزفية في عينة البحث من مقطوعات البيانو للأطفال مصنف

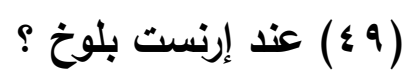

واسنطاعت الباحثة الإجابة على السؤال الثاني في الإطار النطبيقى من خلاد التحليل العزفي

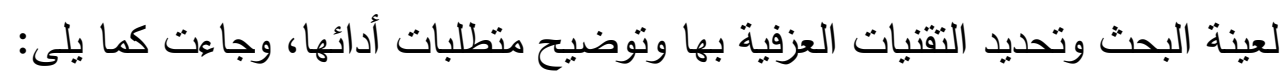
ا - أداء مسافات لحنية صاعدة وهابطة متصلة في نطاق صوتى قريب باليدين بأقواس لحنية

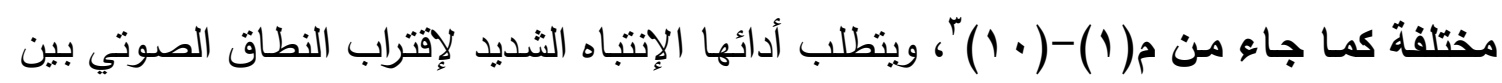

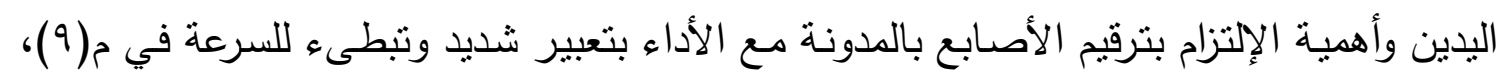

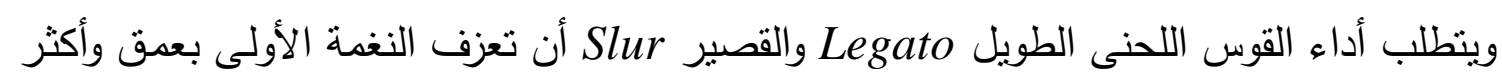

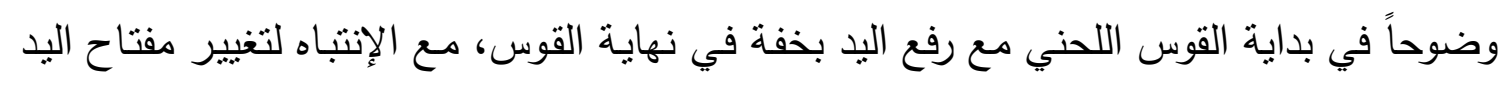

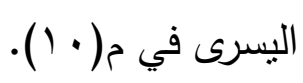

مجلة علوم وفنون الموسيقى - كلية التربية الموسيقية ـ المجلد الرابع و الأربعون -

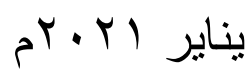




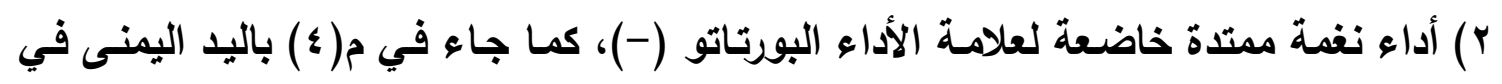
المقطوعة الأولى، وينطلب أدائها أن تعطى النغمة الممتدة باليد اليمنى مدتها الزمنية كاملة وأدائها لوائها

بوضوح بالضغط بقوة على النغمة المشار إليها بالعلامة (-).

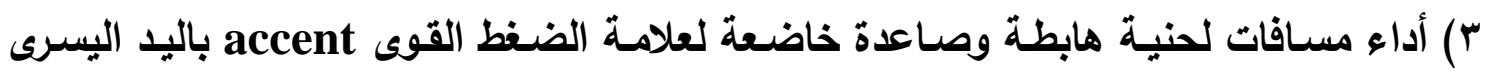

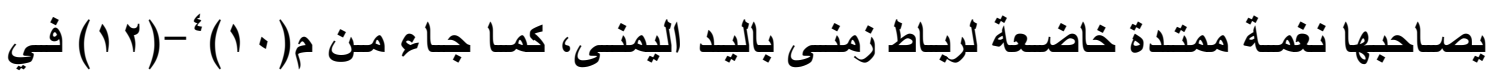

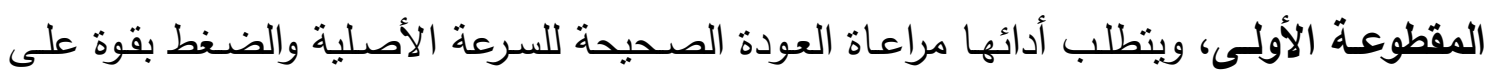
المسافات اللحنية والضغط بقوة على نغمة (رى) باليمنى للحفاظ على إستمرار الصوت.

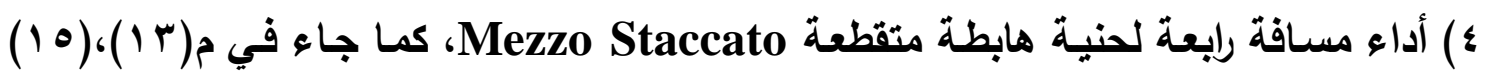
باليد اليسرى في المقطوعة الأولى، وبتطلب أدائها أن يفصل بين النغمنين سكتة قصيرة تعادل ربع قيمتها الزمنية وتأخذ كل نغمة ثلاثة أرباع قيمتها الزمنية، مع الإنتباه لتغير الميزان.

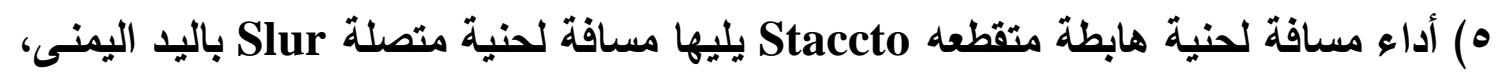

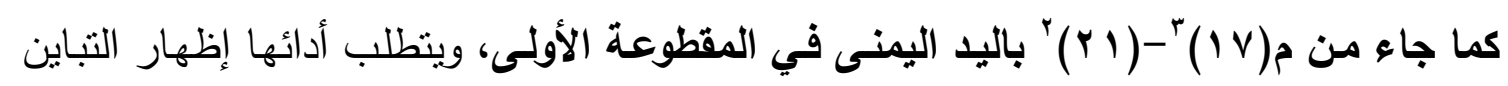

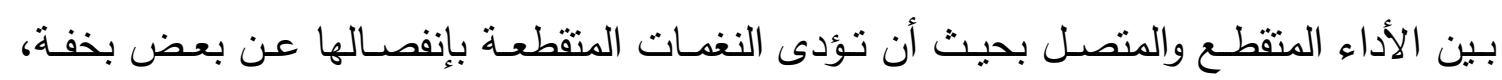

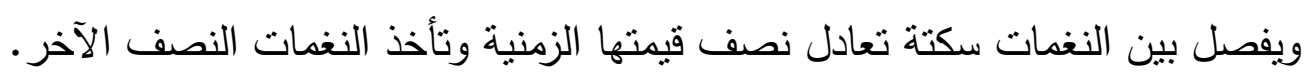

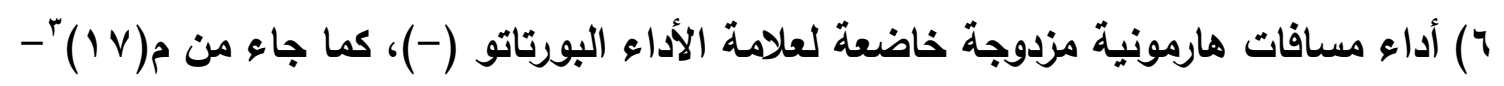

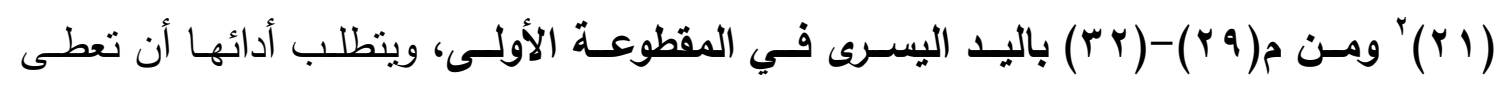

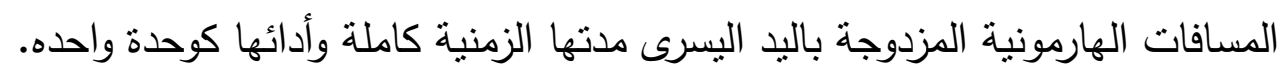

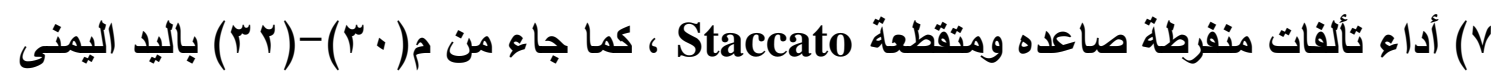
في المقطوعـة الأولسى، ويتطلب أدائها أن تكون أصابع اليد على إستعداد لأداء المسافات أثناء

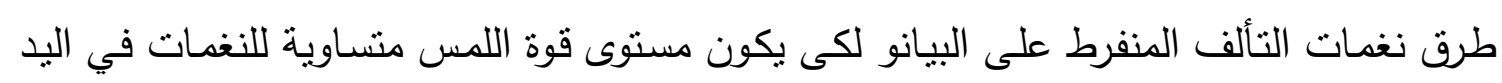
اليمنى مع الإلتزام بنرقيم الأصابع بالمدونة، ويتطلب أداء العزف المتقطع كما سبق ذكره.

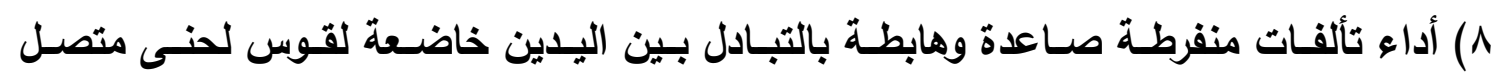

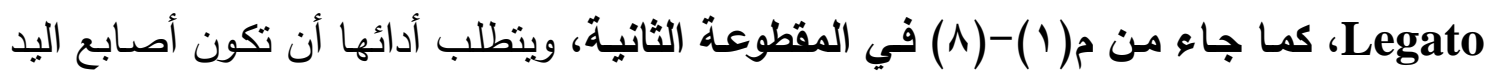

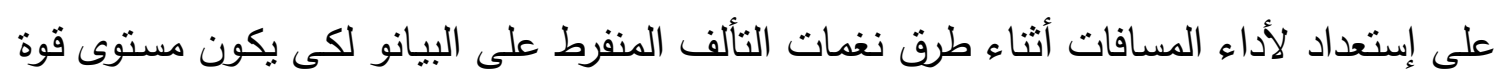

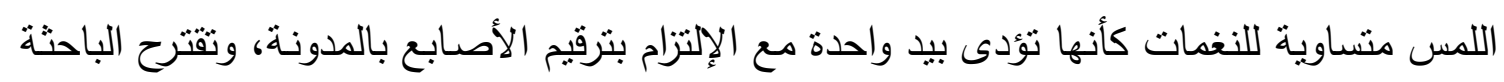

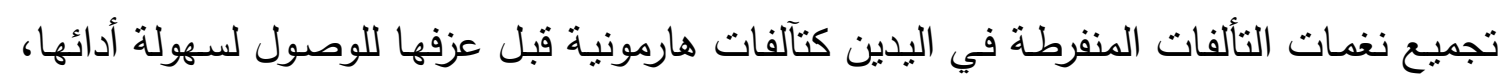
وينطلب أداء القوس اللحنى المنصل كما سبق ذكره.

مجلة علوم وفنون الموسيقى - كلية التربية الموسبقية ـ المجلد الر ابع و الأربعون -

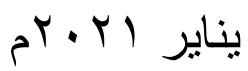




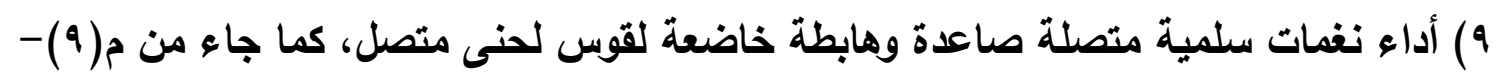

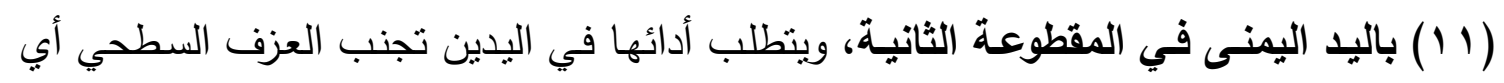

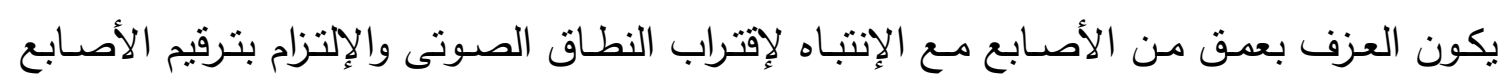

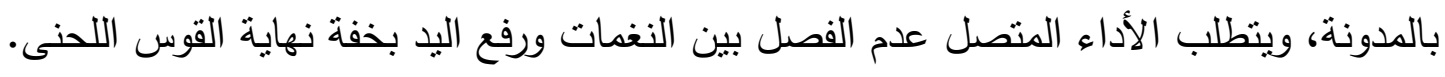

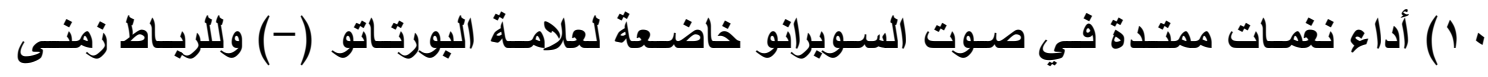

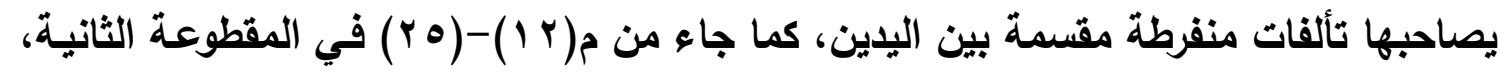

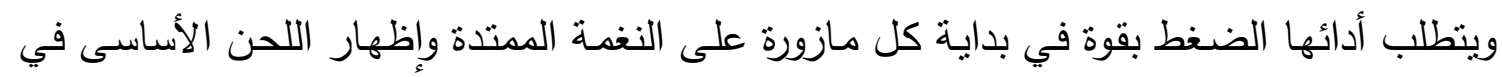

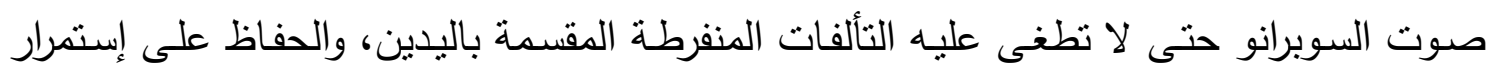

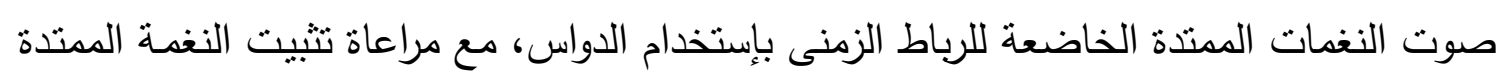

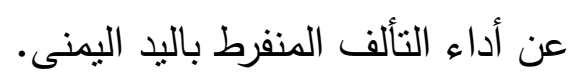
1) أداء نموذج لحنى وإيقاعى ثابت ومتكرر يحتوى على مسافات لحنبـة صـاعدة وهابطة

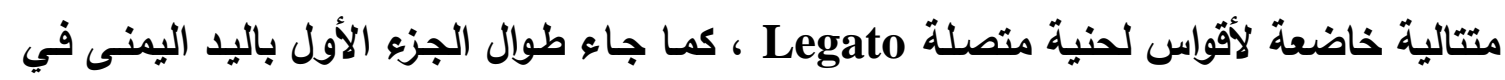
المقطوعـة الثاثثة، ويتطلب أدائها التركيز لكثرة تغيير المسافات اللحنيـة وأهميـة الإلنزام بترقيم

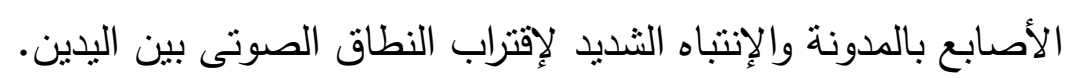

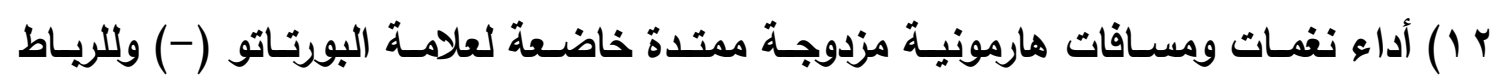

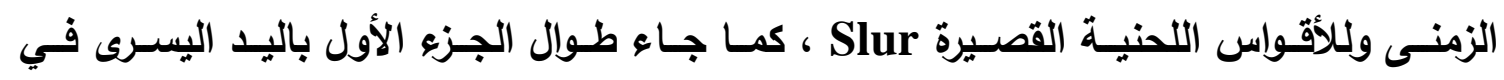

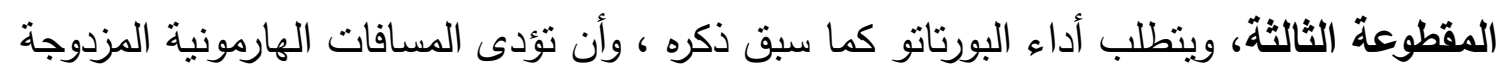

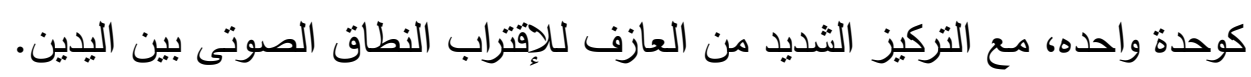

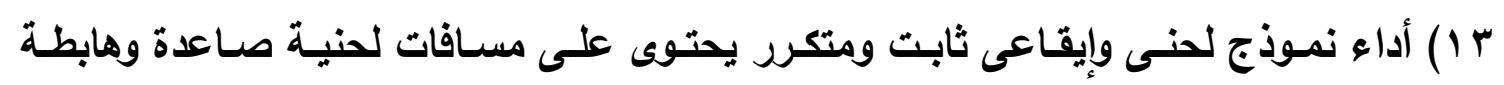

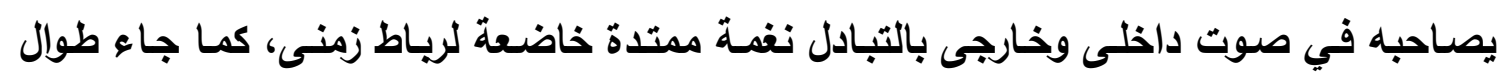

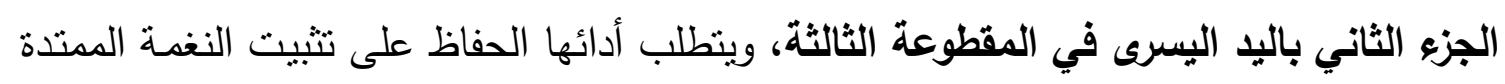
في الصوت الداخلى والخارجى بإستخدام الدواس.

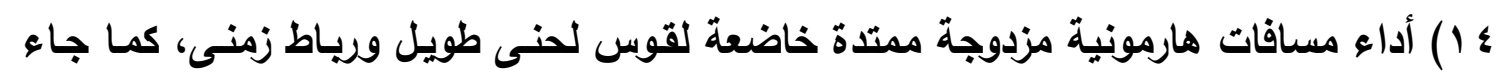

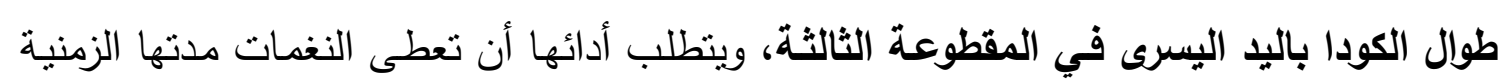
كاملة والحفاظ على الأداء المنصل للنغمات، وأن تؤدى المسافات المزدوجة كوحدة واحده.

مجلة علوم وفنون الموسيقى - كلية التربية الموسيقية ـ المجلد الرابع و الأربعون -

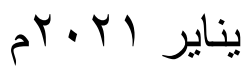




\section{توصيات البحث: - ت ت}

1- توفير المدونات الموسيقية لمقطوعات البيانو للأطفال مصنف (9 ؟) عند إرنست بلوخ بمكتبة كلية التربية الموسيقية - جامعة حلوان لكى تكون في متتاول دارسى البيانو المبتدئين.

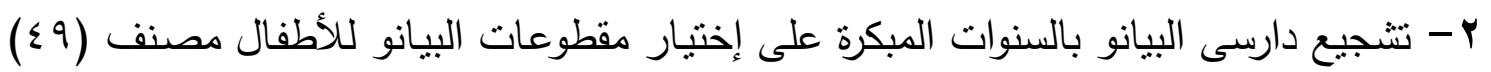
عند إرنست بلوخ كمقطوعات ضمن منـاهج عزف البيانو في مرحلـة البكالوريوس بكلية التربيـة الموسيقية - جامعة حلوان. r- على دارسى البيانو المبتدئين بمرحلة البكالوريوس الإستفادة من البحث الراهن عند إختبار أحد

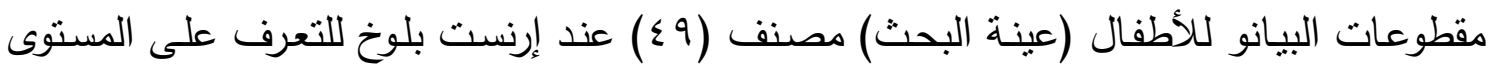
العزفي لجميع المقطوعات والتقنيات العزفية بعينة البحث ومنطلبات أدائها. مراجع البحث:

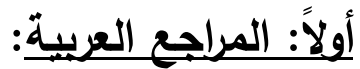

1 - آمال صادق وفؤاد أبو حطب: "مناهج البحث وطرق التحليل الإحصائي"، مكتبة الأنجلو المصرية،

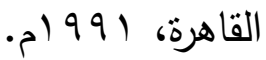
ץ- عواطف عبد الكريم: "محيط الفنون الجزء الثناني"، موسيقي القرن العشرين، دار المعارف، القاهرة، .0197 . ثانياً: المراجع الأجنبية:

3- Agay, Denes:"Teaching Piano", Hamilton Printing Company, Vol.1, New York, 1981.

4- Ernest Bloch: "Ernest Bloch: biography and comment", Michigan University Publishers, USA, 1925, P.5.

5- James Friskin, Irwin Freundlich: "Music for the Piano", New York, 1973.

6- Randel, Michael: "The Harvard Concise Dictionary of Music and Musicians", Harvard College Press, U.S.A, 1999.

7- Sadie, Stanly: "The New Grove Dictionary of Music and Musician", Macmillan Publishers Limited, U.S.A, 2001.

8- www.allMusic.com/biography/Ernest Bloch.

9- www.ernestblochsociety.com/biography.

10- www.thinkexist.com.

مجلة علوم وفنون الموسيقى - كلية التربية الموسبقية ـ المجلد الر ابع و الأربعون -

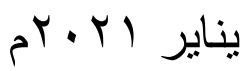




$$
\text { ملحق رقم (1) }
$$

إستمارة إستطلاع أراء الأساتذة الخبراء والمتخصصين في تحليد المستوى العزفى المقترح لمقطوعات البيانو للأطفال مصنف (9 ؛) عند إرنست بلوخ، والتقتيات العزفية في المقطوعات عينة البحث

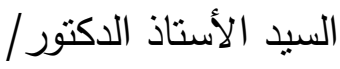

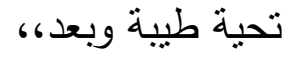

تتشرف الباحثة / زينب عبد الفتاح إبراهيم الددرس بكلية التربية الموسيقة - جامعة حلوان،

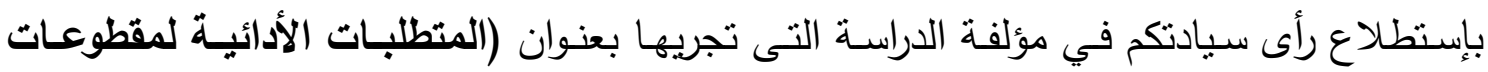
البيانو للأطفال مصنف (9 ؛) عند "إرنست بلوخ" (Ernest Bloch) من حيث المستوى العزفي

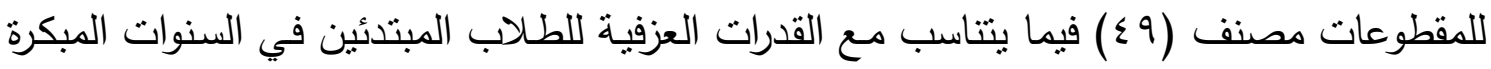

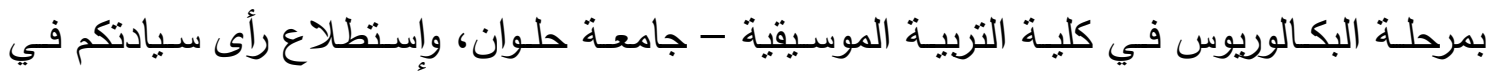

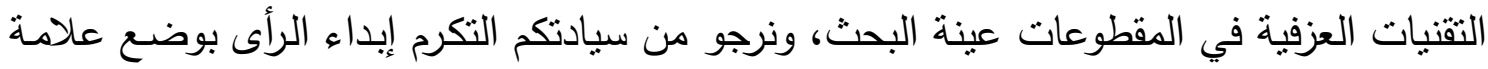
(ل) في الخانة النى تبين رأى سيادنكم مع النكرم بإضافة مقترحانكم إن أمكن.

والباحثه تتقام بخالص الثكر

والتقير لحسن تعاونكم

مجلة علوم وفنون الموسيقى - كلية التربية الموسيقية ـ المجلد الرابع والأربعون -

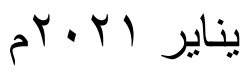




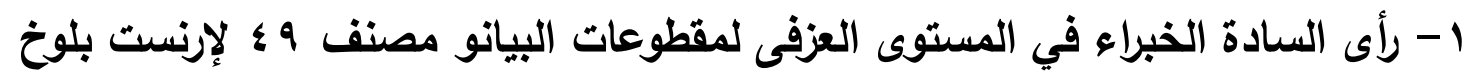

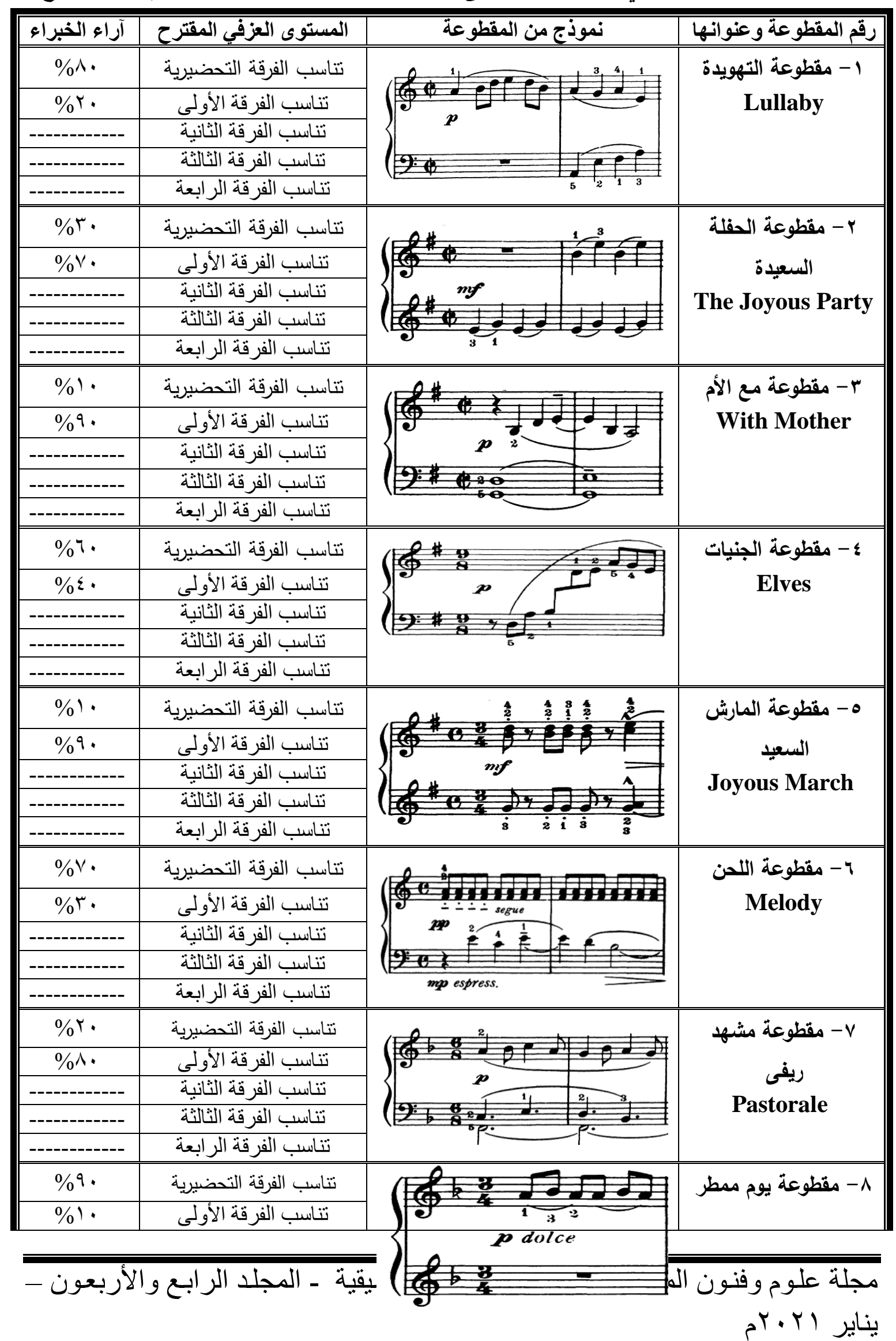




\begin{tabular}{|c|c|c|c|}
\hline -------------- & تناسب الفرقة الثانية & & \multirow[t]{3}{*}{ Rainy Day } \\
\hline ------------- & تناسب الفرقة الثالثة & & \\
\hline ------------- & تتاسب الفرقة الر ابعة & & \\
\hline آراء الخبراء & المستوى العزفي المقترح & نموذج من المقطوعة & رقم المقطوعة وعنوانها \\
\hline$\% \vee \cdot$ & تتاسب الفرقة التحضيرية & \multirow{5}{*}{ 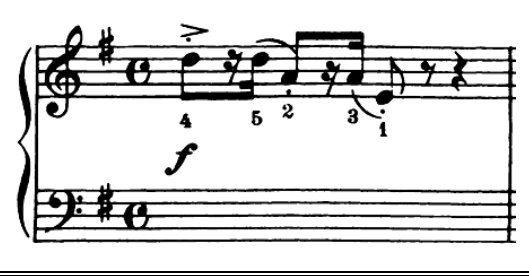 } & \multirow{5}{*}{$\begin{array}{c}\text { - مقطوعة المضايقة } \\
\text { Teasing }\end{array}$} \\
\hline$\%$ & تناسب الفرقة الأولىى & & \\
\hline ------------ & تناسب الفرقة الثانية & & \\
\hline ----------- & تناسب الفرقة الثالثة & & \\
\hline ------------- & تتاسب الفرقة الر ابعة & & \\
\hline$\% 1$. & تتاسب الفرقة التحضيرية & \multirow{5}{*}{$\frac{b^{b}}{8}$} & \multirow{5}{*}{. 1 - مقطوعة الحلم } \\
\hline$\%{ }^{9}$. & تناسب الفرقة الأولى & & \\
\hline -------------- & تناسب الفرقة الثانية & & \\
\hline ------------ & تناسب الفرقة الثالثة & & \\
\hline ------------ & تناسب الفرقة الر ابعة & & \\
\hline
\end{tabular}

r - رأى السادة الخبراء في التقتيات العزفية بالمقطوعات عينة البحث لإنست بلوخ

\begin{tabular}{|c|c|c|c|c|}
\hline \multicolumn{2}{|c|}{ آراء الخبراء } & \multirow[b]{2}{*}{ التقنيات العزفية بالمقطوعات } & \multirow[b]{2}{*}{ المدونة الموسيقية للتقنيات } & \multirow[b]{2}{*}{ رقم المقطوعة } \\
\hline موافير & 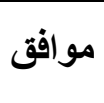 & & & \\
\hline & $\sqrt{ }$ & منصلة في نطاق صنات لحنية صاعدة وهابطة قريب & 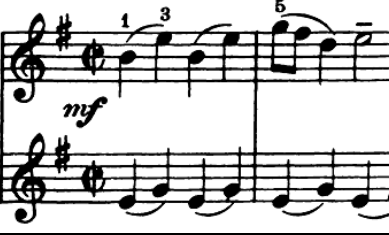 & $\begin{array}{c}\text { مقطوعة الحقلة } \\
\text { السعيدة } \\
\text { The Joyous } \\
\text { Party }\end{array}$ \\
\hline & $\sqrt{ }$ & نغمة ممتدة خاضعة لعلامة الأداء & & \\
\hline & $\sqrt{ }$ & 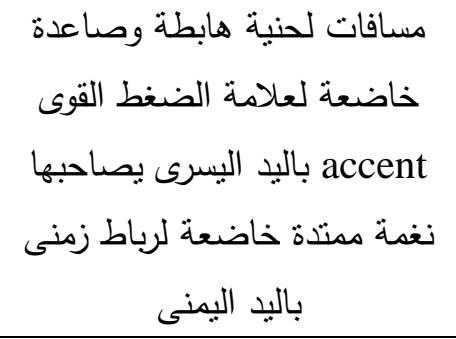 & $\frac{1}{12}$ & \\
\hline & $\sqrt{ }$ & مسافة رابعة لحنية هابطة متقطعة & $y$ & \\
\hline
\end{tabular}

مجلة علوم وفنون الموسيقى - كلية التربية الموسيقية ـ المجلد الر ابع والأربعون -

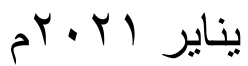




\begin{tabular}{|c|c|c|c|}
\hline$\sqrt{ }$ & مسافة لحنية هابطة منقطعه Staccto & 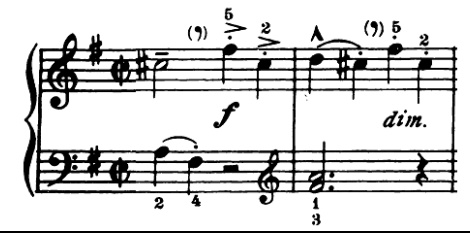 & \\
\hline$\sqrt{ }$ & لعافات هارمونية مزدوجة خاضعة الأداء البورتاتو (-) باليد & J & \\
\hline$\sqrt{ }$ & تألفات منفرطة صاعده ومتقطعة & & \\
\hline$\sqrt{ }$ & 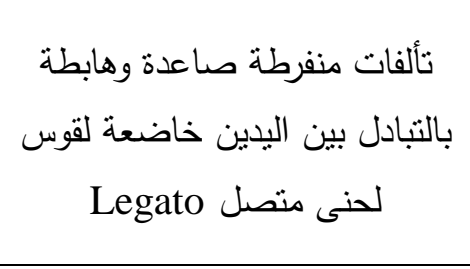 & 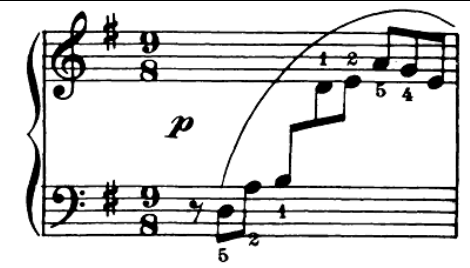 & $\begin{array}{c}\text { مقطوعة الجنيات } \\
\text { Elves }\end{array}$ \\
\hline$\sqrt{ }$ & وهابطة خاضعة سلمية متصلة صلقدس لحنى & $\frac{5}{100}$ & \\
\hline$\sqrt{ }$ & 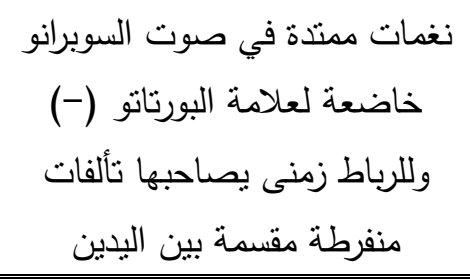 & $=0$ & \\
\hline$\sqrt{ }$ & نمتوذج لحنى وإيقاعى ثنابت ومتكرر & $80+2=2$ & مقظوعة يوم ممطر \\
\hline$\sqrt{ }$ & مندمة خاضعة ومسافات هارمونية مزدوجة & $\frac{2}{\frac{2}{2}}$ & \\
\hline
\end{tabular}

مجلة علوم وفنون الموسيقى - كلية التربية الموسيقية ـ المجلد الرابع والأربعون يناير الr.r 


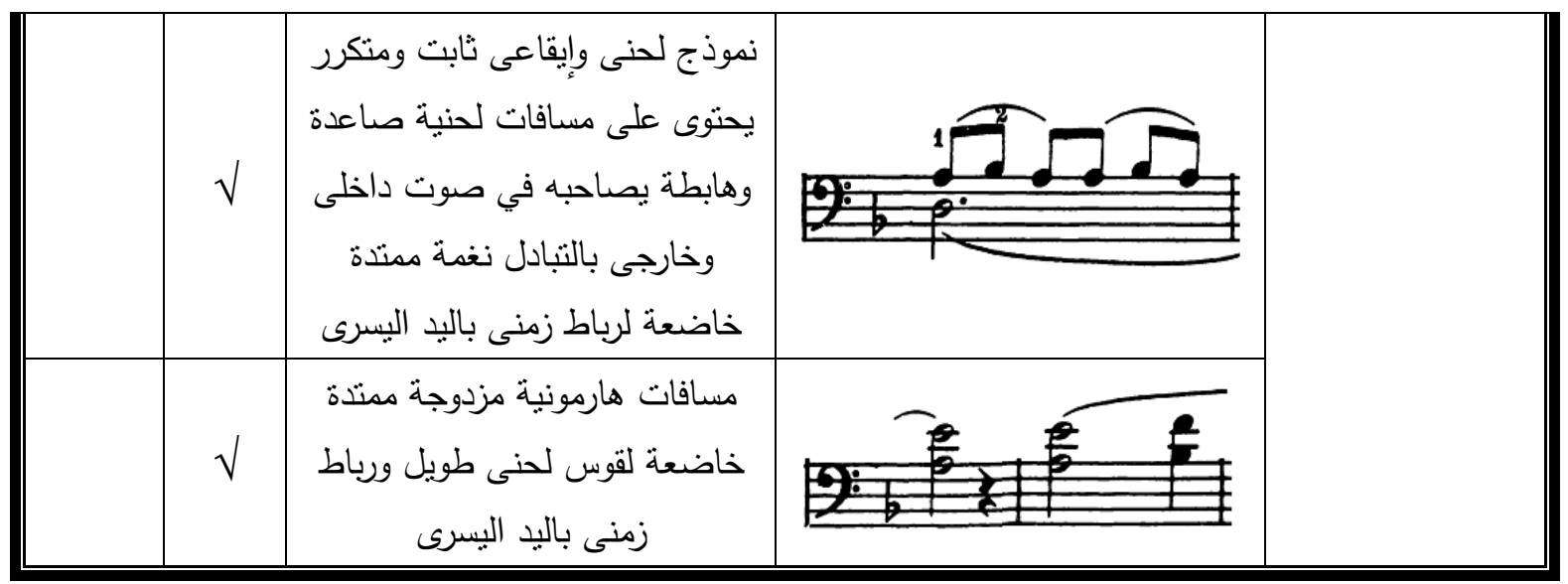

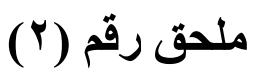

قائمة بأسماء الأساتذة الخبراء والمتخصصين الأين أسدوا بآرائهم في إستمارات إستطلاع الآراء

\begin{tabular}{|c|c|}
\hline - جامعة حلوان دكتور بقم الأداء - شعبة بيانو - كلية التربية الموسيقية & أ.د/ أفكار رفاعى أحمد \\
\hline - جامعة حلواذ دكتور بقسم الأداء - شعبة بيانو - كلية التربية الموسيقية & أ.د/ شريف زين العابدين \\
\hline - جامعة حلواذ دكتور بقم الأداء - شعبة بيانو - كلية التربية الموسيقية & أ.د/ مرفت عبد المنعم غنيمي \\
\hline - جامعة مساذ مساعد بقم الأداء - شعبة بيانو - كلية التربية الموسيقية & م.د/ داليا عبد الحى بدير \\
\hline - جامعة حلواذ مساعد بقسم الأداء - شعبة بيانو - كلية التربية الموسيقية & أ.م.د/ شيماء حمدى عبد الفتاح \\
\hline - جامعتاذ مساعد بقسم الأداء - شعبة بيانو - كلية التربية الموسيقية & ت تبد العاطى \\
\hline
\end{tabular}

مجلة علوم وفنون الموسيقى - كلية التربية الموسيقية ـ المجلد الر ابع و الأربعون -

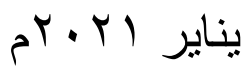




\section{ملخص البحث}

المتطلبات الأدائية لمقطوعات البيانو للأطفال مصنف (9 ؛ ) عند "إرنست بلوخ"

\section{Ernest Bloch}

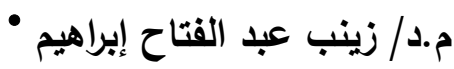

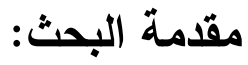

في بدايـة القرن العشرين عاشـت الموسيقى الأوربيـة في تغير مستمر ونمو مطرد نتيجة

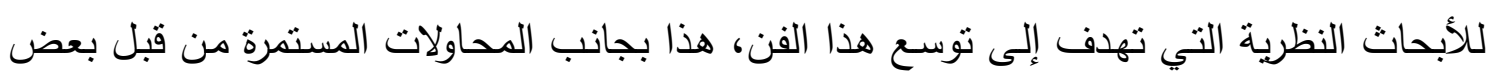
المؤلفين الموسيقيين الرواد لإكتثاف إمكانيات جديدة في مجال الإبداع الفنى والتعبير الموسيقى، لهيق ويعتبر القرن العثرين هو عصر المذاهب الجديدة في الموسيقى، حيث قام جيل جديد من المؤلفين

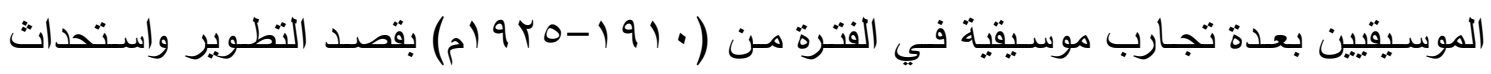

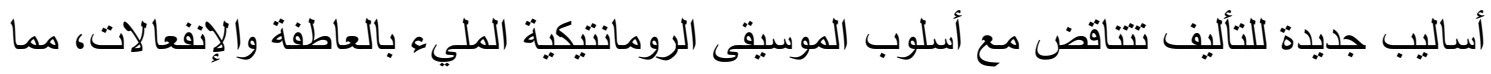
دعاهم لإيجاد أسلوب آخر يعكس روح العصر الذي يعيشون فيه، ولقد إهتم العديد من المؤلقين الموسيقيين منذ بداية القرن العشرين بالجانب التعليمى لآلة البيانو وأعدوا لها مقطوعات لهان للأطفال

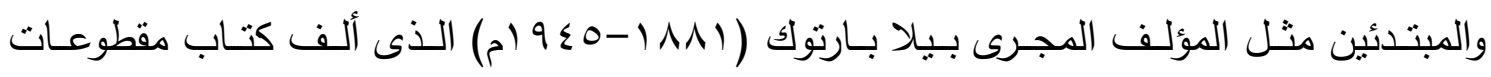

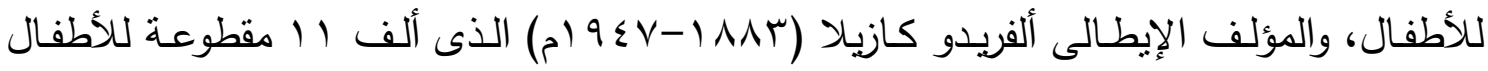

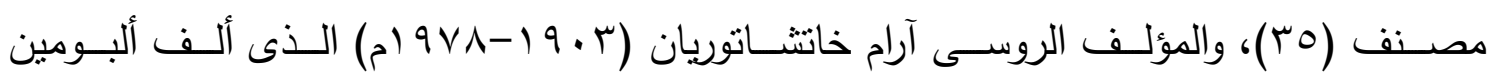

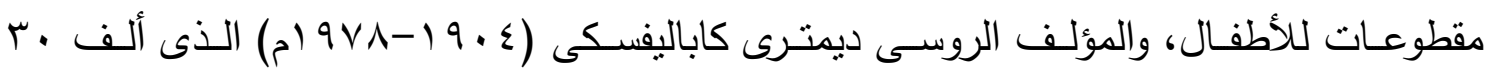

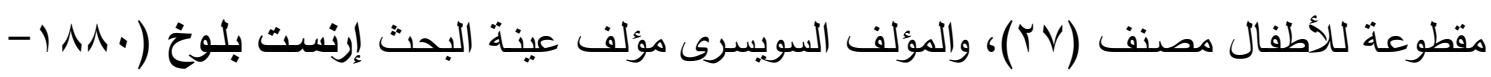

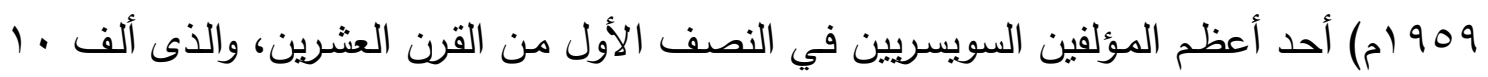

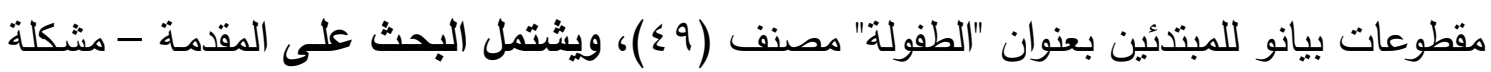

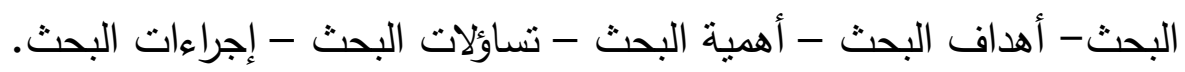
وينقسم البحث إلى جزئين: الجزء الأول: الإطار النظري ويشتمل على النى 1- بعض مقطوعات البيانو للمبندئين في القرن العشرين. r- مؤلفات إرنست بلوخ لآلة البيانو. r- نشأة وحياة إرنست بلوخ.

• مدرس دكتور بقسم الأداء - شعبة بيانو - كلية التربية الموسيقية - جامعة حلوان.

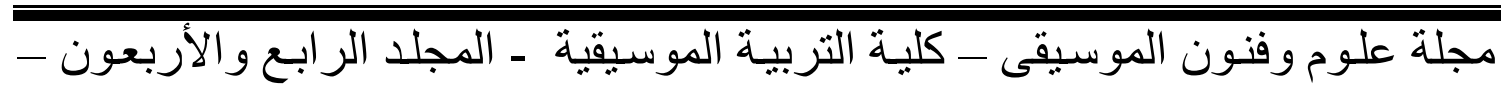

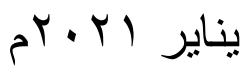


الجزء الثاني: الإطار التطبيقي ويشتمل على

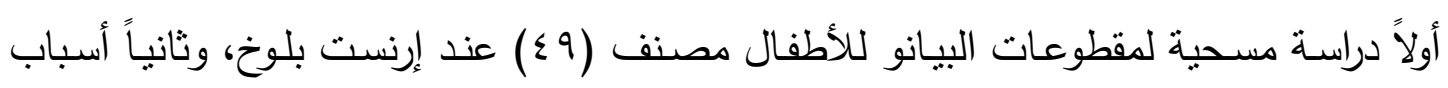

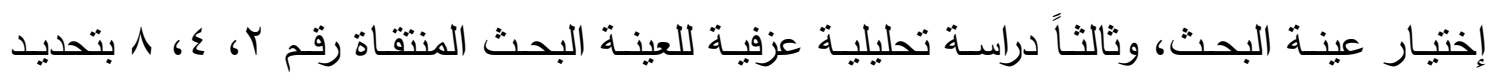

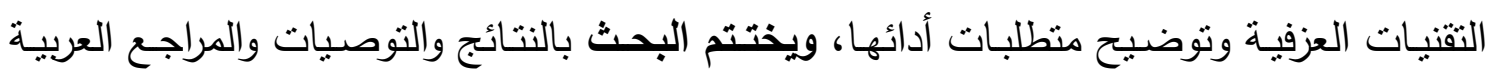
والأجنبية وملاحق البحث وملخص البحث باللغة العربية والأجنبية.

مجلة علوم وفنون الموسيقى - كلية التربية الموسبقية ـ المجلد الر ابع و الأربعون -

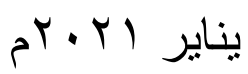




\section{Abstract of the Research \\ Performance Requirement for Children Piano Pieces Opus.49 by Ernest Bloch}

- Zeinab Abd El Fattah Ibrahim

At the beginning of the $20^{\text {th }}$ century European music lived in constant chang and growth as a result of theoretical research aimed at the development this art, this is addition to the continuous attempts of pioneering music composers to discover anew possibility in the field of music creativity, the $20^{\text {th }}$ century is considered the age of new doctrines in music, where a new generation of musical composers performed several musical experiments from 1910 to 1925 with the intention of developing and creating new methods of compositions that contradict the romantic music style full of passion, which led them to find another style that reflects the spirits of the times in which they live, the musical composers Since the Beginning of $\mathbf{2 0}^{\text {th }}$ century paid attention to the educational aspect of the piano and prepared pieces for children and beginners, such as the Hungrian Composer Béla Bartók (1881-1945) who composed piano pieces book for children, the Italian composer Alfred Cassella (1883-1947) who composed eleven piano pieces for children op.35, the Russian composer Aram Khachadorian (1903-1978) who composed two album`s Piani pieces for chihdren, the Russian composer Dimitri kabalevsky (19041978) who composed thirteen piano pieces for children op.27, and the Swiss composer who Composed the research sample Ernest Bloch (18801959 ) one of the greatest Swiss composers in the first half of the $20^{\text {th }}$ century who composed ten piano pieces for beginners op.49.

The research includes:

Introduction, Problem, Objectives, Importance, Questions, and Procedures, terms of the Research.

The research divided into:

First part: Theoretical frame: its includes

-Some Piano Pieces for Beginners in the $20^{\text {th }}$ Century.

- Ernest Bloch's Life.

* A teacher in the Performance Department, Piano Division, Faculty of Music Education, Helwan University.

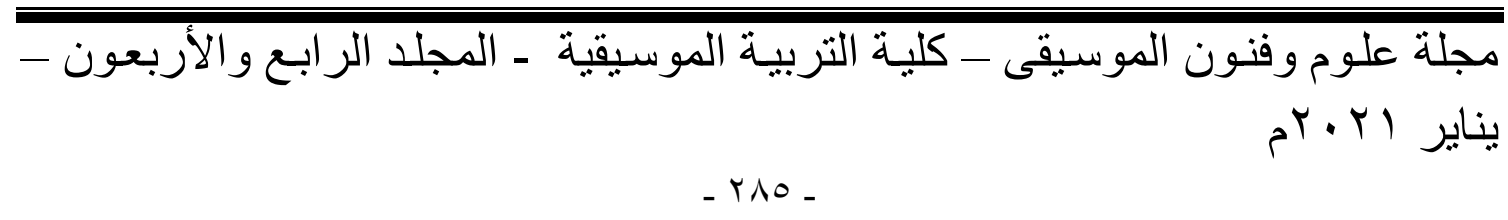


- Ernest Bloch's Piano Compositions.

Second Part: Applied Frame: its includes

Survey study of children's piano pieces opus. 49 by Ernest Bloch,

followed by analytical analysis to clarify the performance requirement of the research sample pieces opus. 49 by Ernest Bloch, Then the research concluded the results, recommendations, references in Arabic and Foreign, research supplements and abstract of the research Arabic and Foreign.

يناير اr. مجلة علوم وفنون الموسيقى - كلية التربية الموسيقية ـ المجلد الرابع والأربعون - 